
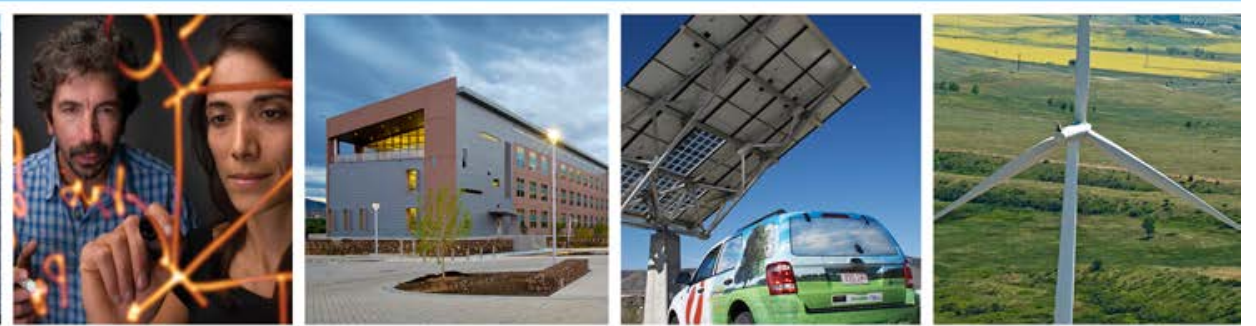

\title{
Feasibility Study of Economics and Performance of Solar Photovoltaics at the TechCity East Campus Resource Conservation and Recovery Act Site in Kingston, New York
}

A Study Prepared in Partnership with the Environmental Protection Agency for the RE-Powering America's Land Initiative: Siting Renewable Energy on Potentially Contaminated Land and Mine Sites

James Salasovich, Jesse W. Geiger, Gail Mosey, and Victoria Healey

Produced under direction of the U.S. Environmental Protection Agency (EPA) by the National Renewable Energy Laboratory (NREL) under Interagency Agreement IAG-09-1750 and Task No. WFD6.1001.

NREL is a national laboratory of the U.S. Department of Energy Office of Energy Efficiency \& Renewable Energy Operated by the Alliance for Sustainable Energy, LLC.

This report is available at no cost from the National Renewable Energy Laboratory (NREL) at www.nrel.gov/publications.

Technical Report NREL/TP-7A40-60599 January 2014 


\section{Feasibility Study of Economics and Performance of Solar Photovoltaics at the TechCity East Campus Resource Conservation and Recovery Act Site in Kingston, New York}

\section{A Study Prepared in Partnership with the Environmental Protection Agency for the RE-Powering America's Land Initiative: Siting Renewable Energy on Potentially Contaminated Land and Mine Sites}

James Salasovich, Jesse W. Geiger, Gail Mosey, and Victoria Healey

Prepared under Task No. WFD6.1001

\section{Technical Report}

NREL/TP-7A40-60599

January 2014

Contract No. DE-AC36-08G028308 


\section{NOTICE}

This report was prepared as an account of work sponsored by an agency of the United States government. Neither the United States government nor any agency thereof, nor any of their employees, makes any warranty, express or implied, or assumes any legal liability or responsibility for the accuracy, completeness, or usefulness of any information, apparatus, product, or process disclosed, or represents that its use would not infringe privately owned rights. Reference herein to any specific commercial product, process, or service by trade name, trademark, manufacturer, or otherwise does not necessarily constitute or imply its endorsement, recommendation, or favoring by the United States government or any agency thereof. The views and opinions of authors expressed herein do not necessarily state or reflect those of the United States government or any agency thereof.

This report is available at no cost from the National Renewable Energy Laboratory (NREL) at www.nrel.gov/publications.

Available electronically at http://www.osti.gov/bridge

Available for a processing fee to U.S. Department of Energy and its contractors, in paper, from:

U.S. Department of Energy

Office of Scientific and Technical Information

P.O. Box 62

Oak Ridge, TN 37831-0062

phone: 865.576 .8401

fax: 865.576 .5728

email: mailto:reports@adonis.osti.gov

Available for sale to the public, in paper, from:

U.S. Department of Commerce

National Technical Information Service

5285 Port Royal Road

Springfield, VA 22161

phone: 800.553 .6847

fax: 703.605.6900

email: orders@ntis.fedworld.gov

online ordering: http://www.ntis.gov/help/ordermethods.aspx

Cover Photos: (left to right) photo by Pat Corkery, NREL 16416, photo from SunEdison, NREL 17423, photo by Pat Corkery, NREL 16560, photo by Dennis Schroeder, NREL 17613, photo by Dean Armstrong, NREL 17436, photo by Pat Corkery, NREL 17721. 


\section{Acknowledgments}

The National Renewable Energy Laboratory (NREL) thanks the U.S. Environmental Protection Agency (EPA) for its interest in securing NREL's technical expertise. In particular, NREL and the assessment team for this project are grateful to the facility managers, engineers, and operators for their generous assistance and cooperation. 


\section{Executive Summary}

The U.S. Environmental Protection Agency (EPA), in accordance with the RE-Powering America's Land initiative, selected the TechCity East Campus site in Kingston, New York, for a feasibility study of renewable energy production. The National Renewable Energy Laboratory (NREL) provided technical assistance for this project. The purpose of this report is to assess the site for a possible photovoltaic (PV) system installation and estimate the cost, performance, and site impacts of different PV options. In addition, the report recommends financing options that could assist in the implementation of a PV system at the site. This study did not assess environmental conditions at the site.

The TechCity campus is located in Kingston, New York, which is the county seat of Ulster County. Kingston is located 90 miles north of New York City. The TechCity campus is 138 acres, is composed of 28 buildings, and has approximately 2.4 million $\mathrm{ft}^{2}$ of building space. The TechCity campus was originally an International Business Machines Corporation (IBM) campus for building mainframe computers that opened in 1956. The Kingston IBM plant reached its peak in 1985 when 7,100 people were employed there, and it was closed in 1994 when IBM was going through a major restructuring. A developer purchased the Kingston IBM plant in 1998 and renamed it TechCity. The current plan of the site is to offer building space to tech companies that can put to use the existing infrastructure.

The feasibility of installing a PV system on a Resource Conservation and Recovery Act (RCRA) site is highly impacted by the available area for an array, solar resource, distance to transmission lines, and distance to major roads. In addition, the remediation status, ground conditions, and restrictions associated with redevelopment of the RCRA site impact the feasibility of a PV system. Based on an assessment of these factors, the TechCity East Campus is suitable for deployment of a large-scale PV system.

There is a high potential to build out the TechCity East Campus site with roof-mounted PV but very little potential to build out the site with ground-mounted PV because of the high concentration of buildings on the site. There are 17.5 acres $\left(762,300 \mathrm{ft}^{2}\right)$ potentially available for roof-mounted PV systems. This area represents a unique opportunity to deploy utility-scale solar on a rooftop. There are currently no areas available for a ground-mounted PV system at the site. While the entire area does not need to be developed at one time, due to the feasibility of staging installation as area or funding becomes available, calculations for this analysis reflect the solar potential if the total feasible area is used.

Of the five scenarios considered, two had a positive net present value and all had a payback in the analysis period. No single-axis tracking systems were considered because they cannot be installed on roof space. The economic feasibility of a PV system on the TechCity East Campus depends greatly on the price of electricity from Gateway Energy Services and Central Hudson Gas \& Electric. The economics were analyzed using the Central Hudson Gas \& Electric retail rate found on their website of $\$ 0.0653 / \mathrm{kWh}^{1}$ and a wholesale electricity rate of $\$ 0.0232 / \mathrm{kWh}$ for energy sold back to the utility. Table ES-1 shows the current incentives considered.

\footnotetext{
${ }^{1}$ Central Hudson Gas \& Electric Corporation. Accessed October 9, 2013: http://www.cenhud.com/energy_choice/price history.html.
} 
Table ES-1. Summary of Incentives Evaluated

\begin{tabular}{clcr} 
Incentive Title & Modeled Value & Expected End \\
\hline 1. & PV Incentive Program & $\$ 1.5 / \mathrm{W}, \$ 75,000$ cap & $12 / 31 / 2015$ \\
2. & Federal Investment Tax Credit & $30 \%$ of total investment & \\
& & & \\
3. & Net Metering & Net meter up to 2 MW \\
4. & Sales Tax Exemption & $0 \%$ sales tax & - \\
& & & \\
5. & Property Tax Incentive & $100 \%$ of assessed value & -
\end{tabular}

Net metering was applied to only the cases $2 \mathrm{MW}$ and smaller. Other incentives that TechCity was not clearly eligible for were not considered at this time.

Table ES-2 summarizes the system performance and economics of a potential system that would use all available areas surveyed at the TechCity East Campus and smaller variations. The table shows the annual energy output from the system along with the number of average American households that could be powered off of such a system and estimated job creation. The size of a net-metering system was varied to determine a breakeven PV array size and best case economic scenario. The economic breakeven PV array size was found to be $161 \mathrm{~kW}$ and the best case economic scenario is a $50-\mathrm{kW}$ system, which is the maximum size to take advantage of the state capacity-based incentive. If incentives were available for larger systems, however, a larger system would be recommended. The $50-\mathrm{kW}$ system generates $59,387 \mathrm{kWh}$ of electricity and has a net present value of $\$ 24,498$, with 4.5 years to pay back. This includes the current cost of energy, expected installation cost, site solar resource, and existing incentives for the proposed PV system. The savings and payback is deemed reasonable and as such, a solar PV system between $50 \mathrm{~kW}$ and $117 \mathrm{~kW}$ represents a viable reuse for the site under analyzed conditions. 
Table ES-2. TechCity East Campus PV System Summary

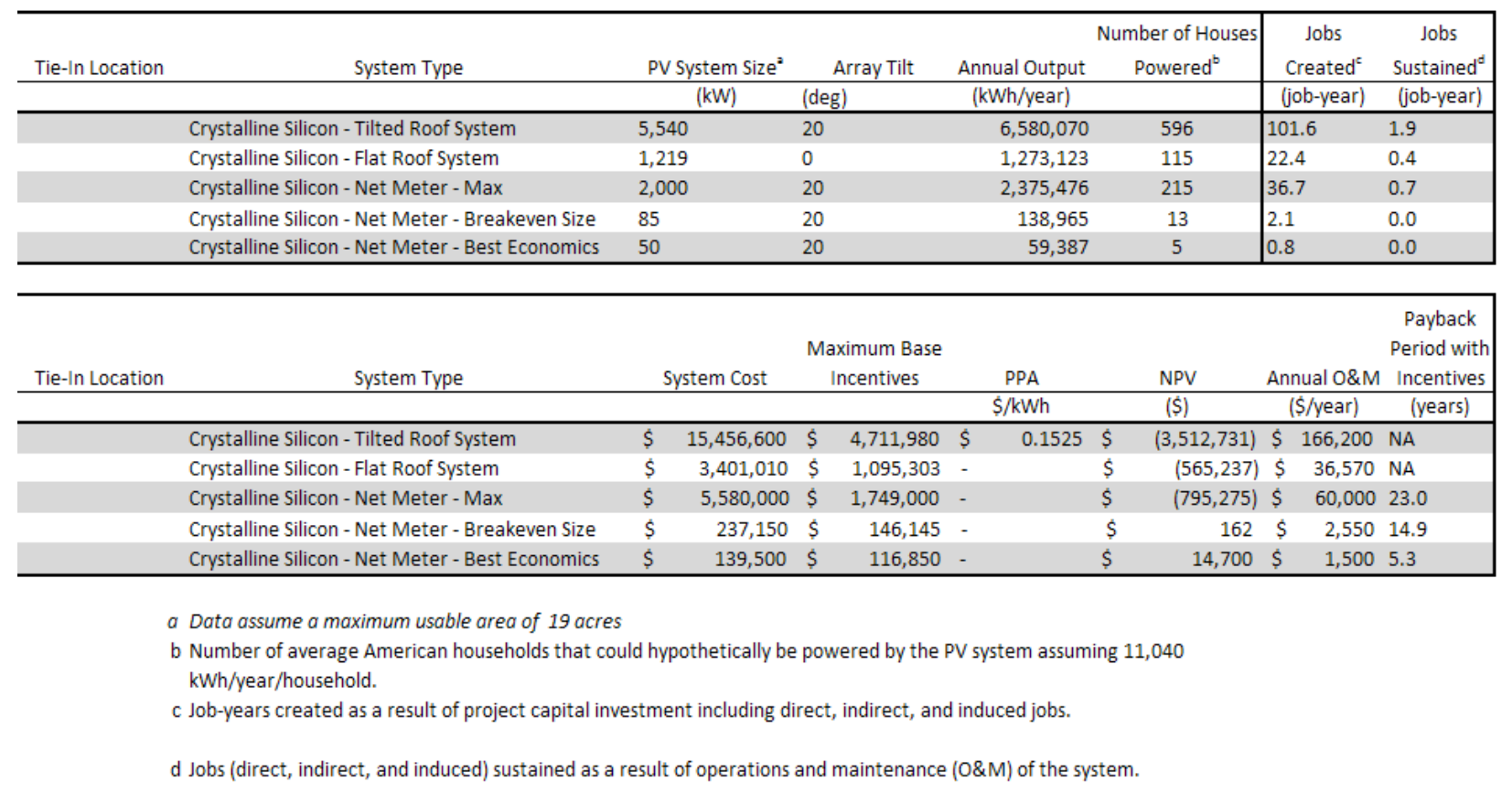

Following completion of the feasibility study, the RE-Powering team identified a potential funding source to improve project economics for large-scale solar systems at the former TechCity site. As part of the NY-Sun Initiative, the New York State Energy Research and Development Authority (NYSERDA) is accepting applications for solar projects of $50 \mathrm{~kW}$ or more. Through a state-side competitive bidding process, NYSERDA plans to provide performance-based incentives on a dollar-per-kilowatt-hour basis. This type of incentive program might improve project economics sufficiently for the deployment of large-scale systems (2-5 MW) at the TechCity site.

A preliminary analysis shows that an incentive of $\$ 0.087 / \mathrm{kWh}$ for a $2-\mathrm{MW}$ system or $\$ 0.195 / \mathrm{kWh}$ for a $5-\mathrm{MW}$ system could provide sufficient returns, in the case where the incentive is not taxable. If taxed, the incentives required to breakeven would increase to $\$ 0.150 / \mathrm{kWh}$ and $\$ 0.332 / \mathrm{kWh}$, respectively.

While the cost of solar energy installations has decreased significantly in recent years, incentives at the federal, state, and/or local level are typically required to be competitive with conventional fuel sources or provide sufficient returns for investors. To achieve the site owner's vision for a utility-scale rooftop system, use of state incentives, such as the NY-Sun Initiative, will likely be required for near-term development. 


\section{Table of Contents}

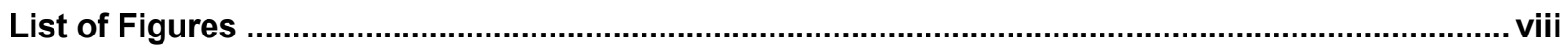

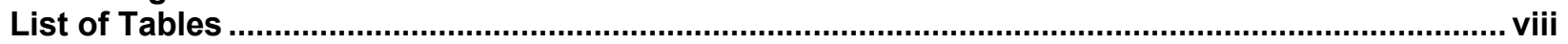

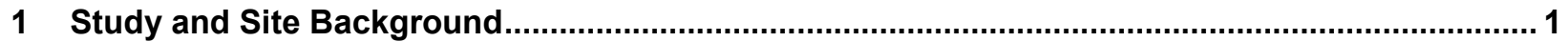

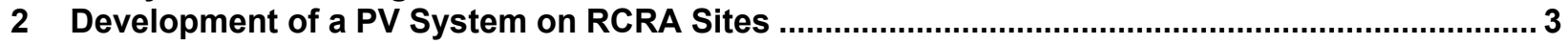

3 PV Systems

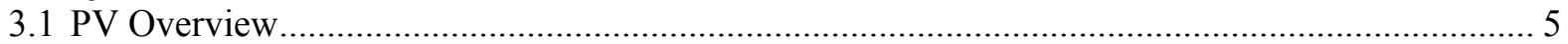

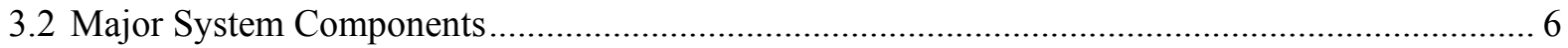

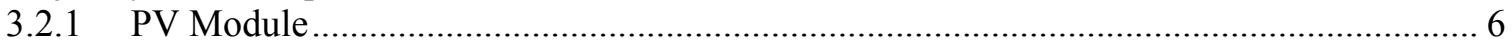

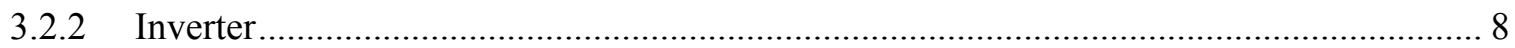

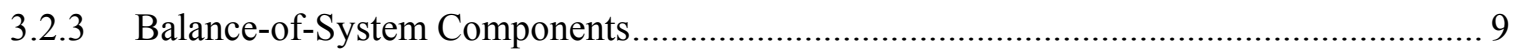

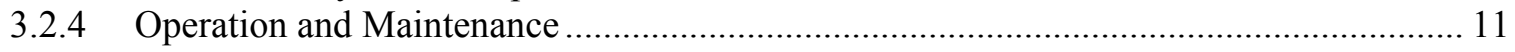

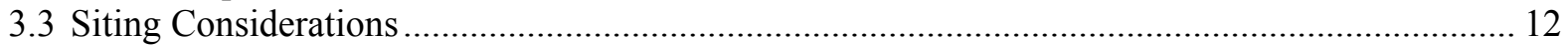

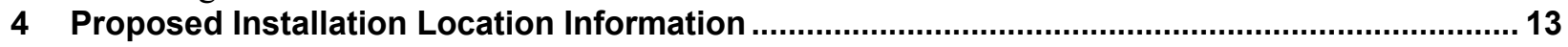

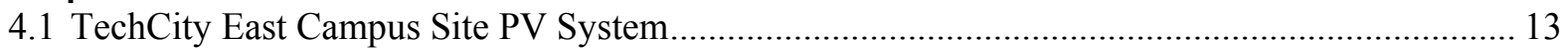

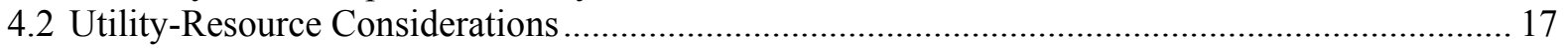

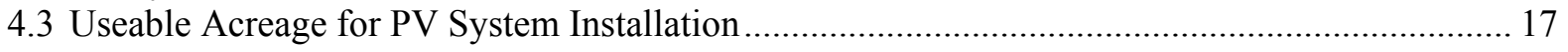

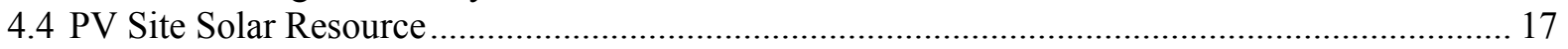

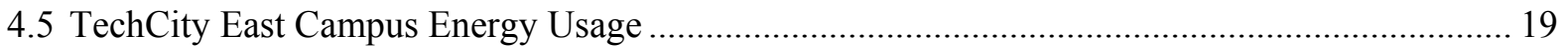

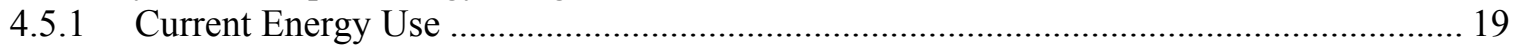

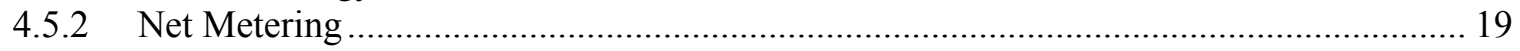

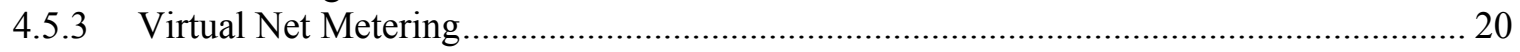

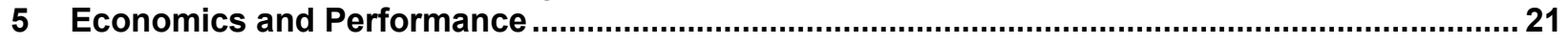

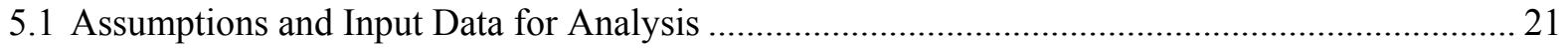

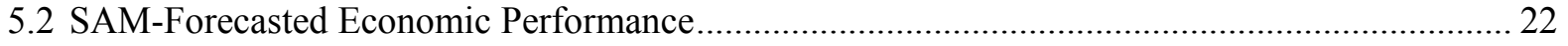

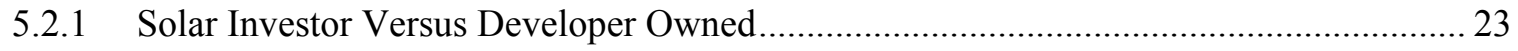

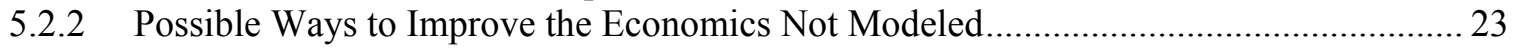

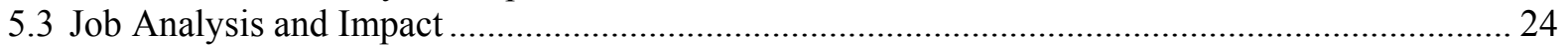

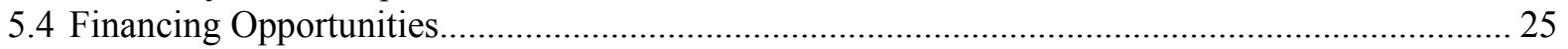

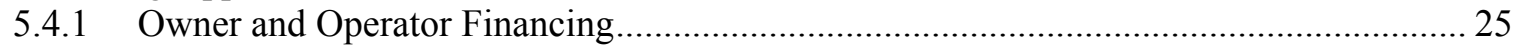

5.4.2 Third-Party Developers With Power Purchase Agreements ........................................ 25

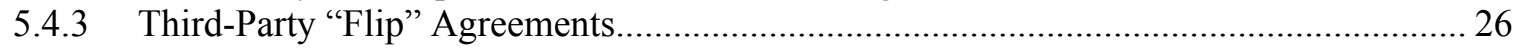

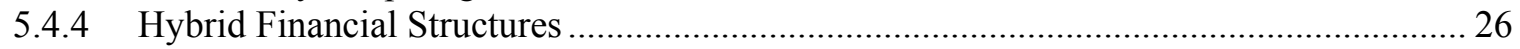

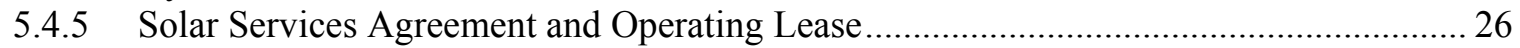

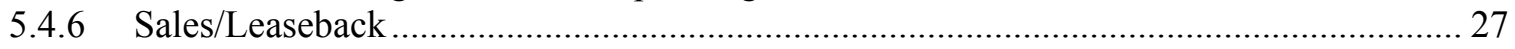

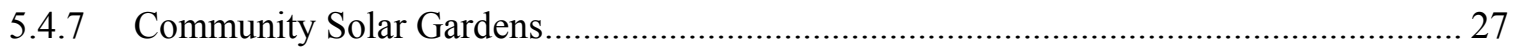

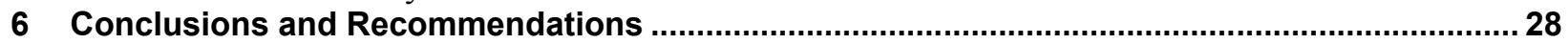

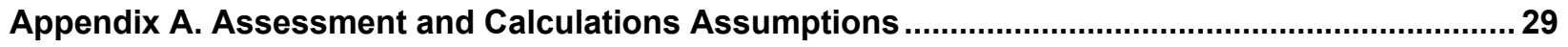

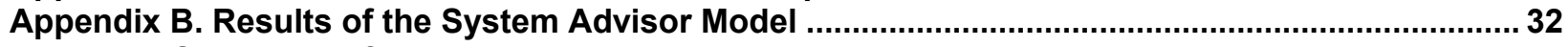

Appendix C. Results of the Jobs and Economic Development Impact Model .................................. 42 


\section{List of Figures}

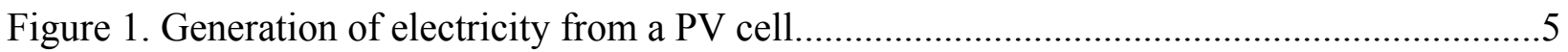

Figure 2. Ground-mounted array diagram ...........................................................................6

Figure 3. Mono- and multi-crystalline solar panels ..................................................................

Figure 4. Thin-film solar panels installed on a (left) solar energy cover and (middle/right)

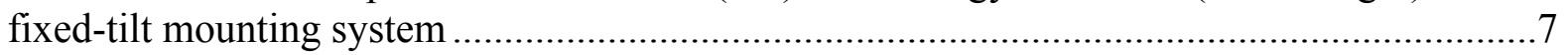

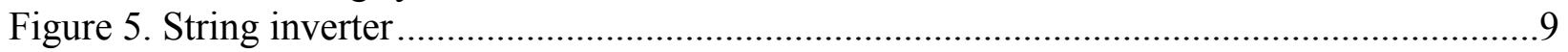

Figure 6. Aerial view of the feasible areas for PV at the Tech City East Campus .........................14

Figure 7. Views of the feasible area for roof-mounted PV on Building 1 at the TechCity East Campus.

Figure 8. Views of the feasible area for roof-mounted PV on Building 52 at the TechCity

East Campus.

Figure 9. View of the feasible area for roof-mounted PV on Building 43 at the TechCity

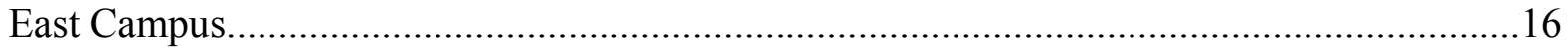

Figure 10. Location of the Lincoln Park substation in relation to the TechCity East Campus .....17

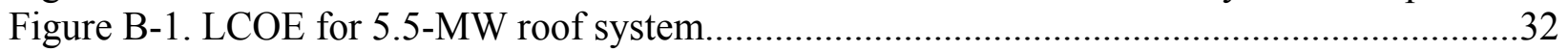

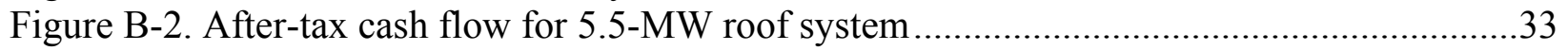

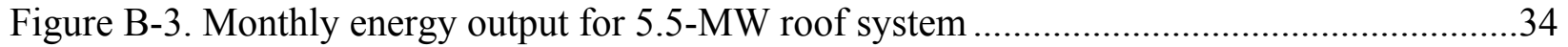

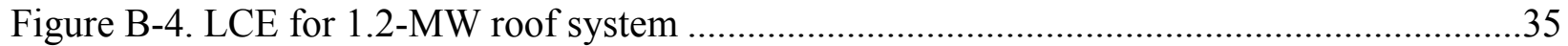

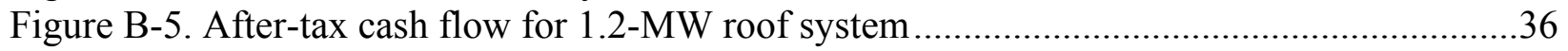

Figure B-6. Monthly energy output for 1.2-MW roof system ....................................................3

Figure B-7. LCOE for 2-MW net-metering roof system .........................................................

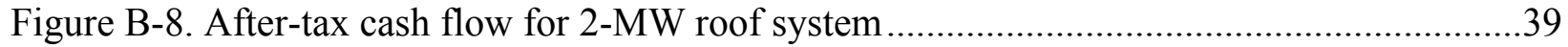

Figure B-9. Monthly energy output for 2-MW roof system ......................................................4

Figure B-10. Net-metering size determination for 2-MW roof system .........................................41

\section{List of Tables}

Table 1. Ground-Mounted Energy Density by Panel and System ...............................................10

Table 2. Rooftop Energy Density by Panel ...........................................................................

Table 3. Site Identification Information and Specifications .....................................................18

Table 4. Performance Results for 20-Degree Fixed-Tilt PV .....................................................19

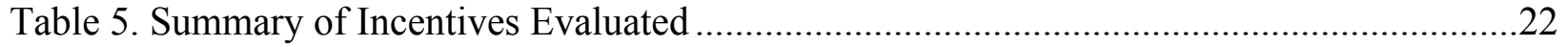

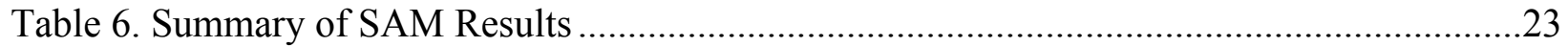

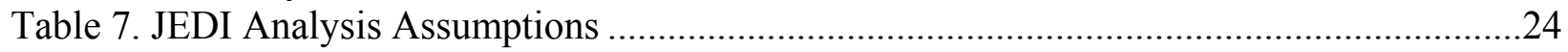

Table A-1. Cost, System, and Other Assessment Assumptions ..................................................29

Table A-2. Cost, System, and Other Assessment Assumptions …………………...........................

Table C-1. Photovoltaic Project Data Summary 161-kW Roof-Mounted System .........................42

Table C-2. Local Economic Impacts - Summary Results ..............................................................43

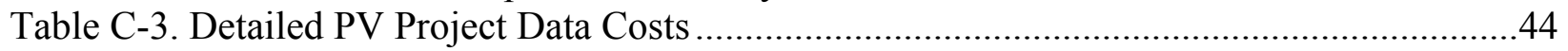

Table C-4. PV System Annual Operating and Maintenance Costs ................................................45 


\section{Study and Site Background}

The U.S. Environmental Protection Agency (EPA), in accordance with the RE-Powering America's Land initiative, selected the TechCity East Campus site in Kingston, New York, for a feasibility study of renewable energy production. The National Renewable Energy Laboratory (NREL) provided technical assistance for this project. The REPowering team assessed the site for a photovoltaic (PV) system installation and estimated the cost, performance, and site impacts of different PV options. In addition, the team recommended financing options that could assist in the implementation of a PV system at the site. This team did not assess environmental conditions at the site.

The TechCity campus is located in Kingston, New York, which is the county seat of Ulster County. Kingston is located 90 miles north of New York City. The TechCity campus is 138 acres and is composed of 28 buildings and has approximately 2.4 million square feet of building space. Kingston had a population of just under 24,000 people in 2011. Kingston experiences summers that are warm and humid with high temperatures typically near $80^{\circ} \mathrm{F}$. The winters are cold and snowy with low temperatures in the $15^{\circ} \mathrm{F}$ to $20^{\circ} \mathrm{F}$ range. Kingston has on average 175 days of sunshine each year. Central Hudson Gas \& Electric Corporation is the utility that provides electricity to TechCity, and it is a deregulated utility.

The TechCity campus was originally an International Business Machines Corporation (IBM) campus for building mainframe computers that opened in 1956. The Kingston IBM plant reached its peak in 1985 when 7,100 people were employed there, and it was closed in 1994 when IBM was going through a major restructuring. A developer purchased the Kingston IBM plant in 1998 and renamed it TechCity. The current plan of the site is to offer building space to tech companies that can put to use the existing infrastructure.

The major contaminants at the site are related to years of manufacturing computers and related components by IBM. The major contaminants include trichloroethane, trichloethylene, and perchlorethylene, which are industrial solvents. The contamination is located in a shallow water table aquifer, and a majority of the contaminants are located under Buildings 1, 2, and 3. ${ }^{2}$ The scope and concentration of the contamination has significantly reduced over time through natural attenuation and a pump-and-treat system operated by IBM. The success of these reductions has resulted in the New York State Department of Environmental Conservation (NYSDEC) issuing "No Action" and "No Further Action" declarations for the site.

The closest electrical tie-in location is right across the street at the Lincoln Park substation. Having a substation within $1,000 \mathrm{ft}$ makes it an ideal location for a PV system to tie into. A detailed interconnection study will have to be performed through a local electric utility, Central Hudson Gas \& Electric Corporation, to determine the feasibility of utilizing the onsite substation as a tie-in point for a PV system. The site currently has

${ }^{2}$ EPA. "IBM Corporation - Kingston.” Accessed October 9, 2013:

http://www.epa.gov/region2/waste/fsibmkin.htm. 
buildings on it, and there are new buildings planned for the future. The buildings on the site are potential off-takers of the electricity produced by a PV system.

Feasibility assessment team members from NREL, Ulster County, TechCity, and EPA conducted a site visit on Thursday, April 5, 2012, to gather information integral to this feasibility study. The team considered information, including solar resource, transmission availability, community acceptance, roof conditions, and ground conditions. 


\section{Development of a PV System on RCRA Sites}

Through the RE-Powering America's Lands initiative, EPA has identified several benefits for siting solar PV facilities on RCRA sites, noting that they:

- Can be developed in place of limited greenfields, preserving the land carbon sink

- Might have environmental conditions that are not well suited for commercial or residential redevelopment and could be adequately zoned for renewable energy

- Are often located near existing roads and energy transmission or distribution infrastructure

- Can provide an economically viable reuse for sites that have significant cleanup costs or low real estate development demand

- Can provide job opportunities in urban and rural communities

- Can advance cleaner and cost-effective energy technologies and reduce the environmental impacts of energy systems (e.g., reduce greenhouse gas emissions).

By taking advantage of these potential benefits, PV can provide a viable, beneficial reuse - in many cases generating significant revenue on a site that would otherwise go unused.

The TechCity East Campus is owned by a developer, Alan Ginsberg, who is interested in potential revenue flows on the site. For many RCRA sites, the local community has significant interest in the redevelopment of the site, and community engagement is critical to match future reuse options to the community's vision for the site. For the TechCity East Campus, the vision of the community aligns well with the vision of the developer. The purpose of this study is to analyze all options so that an informed decision can be made on how to best utilize the site.

Understanding opportunities studied and realized by other similar sites demonstrates the potential for PV system development. The City Solar project in Chicago, Illinois, is the largest urban PV system in the United States, and it is built on a contaminated site. The brownfield site is a former industrial site that had been vacant for 30 years. The 41 -acre site is owned by the City of Chicago and leases the land to a solar developer. The City Solar project was completed in 2010 and is a 10-MW single-axis tracking system. ${ }^{3}$

The TechCity East Campus has potential to be used for other functions beyond the solar PV systems proposed in this report. Any potential use should align with the community vision for the site and should work to enhance the overall utility of the property. There is potential to build light industrial buildings on the site.

There are many compelling reasons to consider moving toward renewable energy sources for power generation instead of fossil fuels, including:

\footnotetext{
${ }^{3}$ Exelon. "Exelon City Solar." Accessed July, 2012: http://www.exeloncorp.com/PowerPlants/exeloncitysolar/Pages/Profile.aspx.
} 
- Renewable energy sources offer a sustainable energy option in the broader energy portfolio

- Renewable energy can have a net positive effect on human health and the environment

- Deployment of renewable energy bolsters national energy independence and increases domestic energy security

- Long-term power purchase agreements (PPAs) linked to renewable energy systems can mitigate fluctuating electric costs by locking in electricity rates

- Renewable energy sources generate energy without harmful emissions or waste products. 


\section{PV Systems}

\subsection{PV Overview}

Solar PV technology converts energy from solar radiation directly into electricity. Solar PV cells are the electricity-generating component of a solar energy system. When sunlight (photons) strikes a PV cell, an electric current is produced by stimulating electrons (negative charges) in a layer in the cell designed to give up electrons easily. The existing electric field in the solar cell pulls these electrons to another layer. By connecting the cell to an external load, this current (movement of charges) can then be used to power the load (e.g., light bulb).

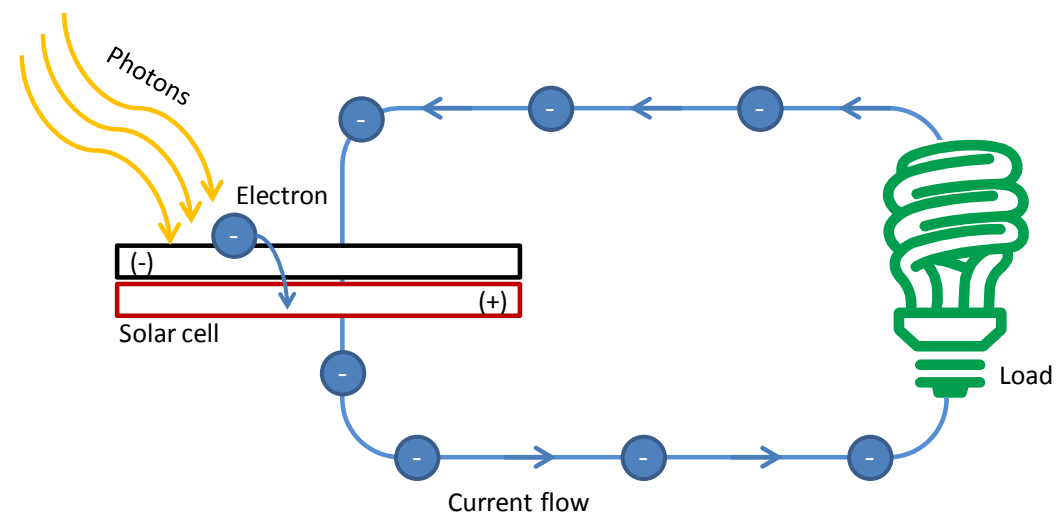

Figure 1. Generation of electricity from a PV cell

Source: EPA

PV cells are assembled into a PV panel or module. PV modules are then connected to create an array. The modules are connected in series and then in parallel as needed to reach the specific voltage and current requirements for the array. The direct current (DC) electricity generated by the array is then converted by an inverter to useable alternating current $(\mathrm{AC})$ that can be consumed by adjoining buildings and facilities or exported to the electricity grid. PV system size varies from small residential $(2-10 \mathrm{~kW})$, to commercial $(100-500 \mathrm{~kW})$, to large utility scale $(10+\mathrm{MW})$. Central distribution plants are also currently being built in the 100+ MW scale. Electricity from utility-scale systems is commonly sold back to the electricity grid. 


\subsection{Major System Components}

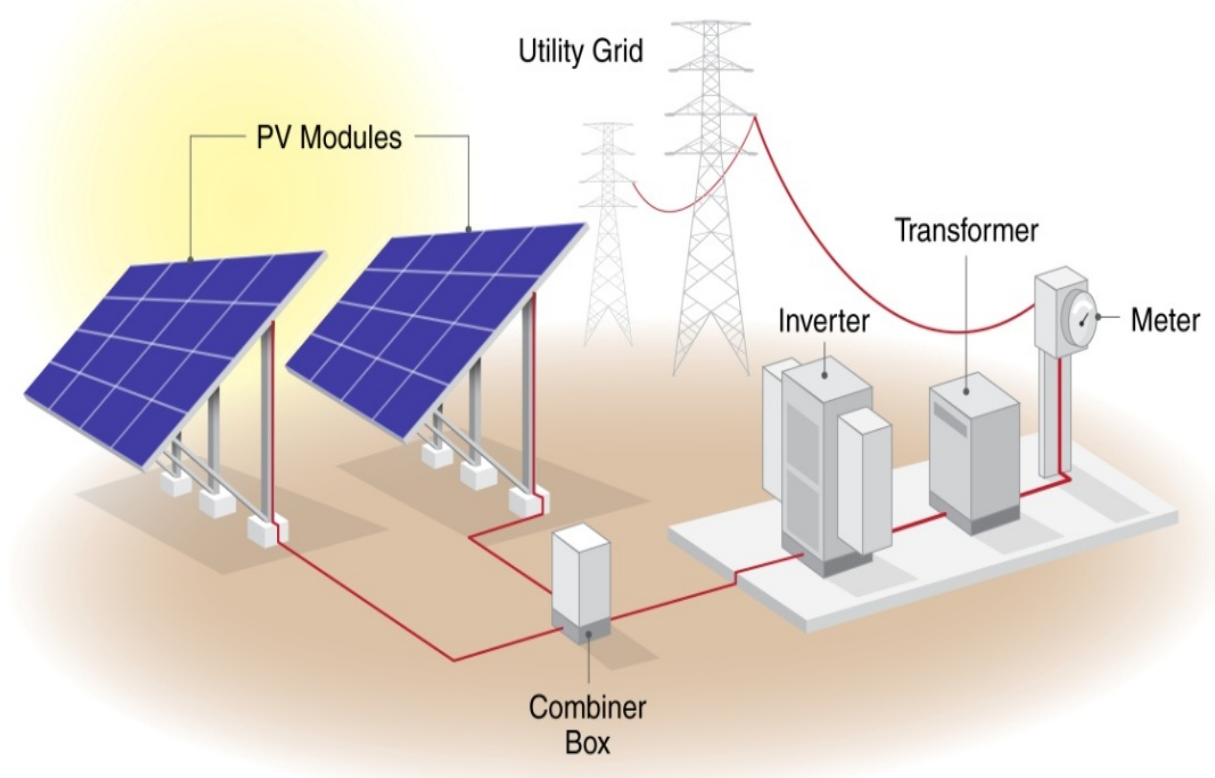

Figure 2. Ground-mounted array diagram

Source: NREL

A typical PV system is made up of several key components, including:

- PV modules

- Inverter

- Balance-of-system (BOS) components.

These, along with other PV system components, are discussed in turn below.

\subsubsection{PV Module}

Module technologies are differentiated by the type of PV material used, resulting in a range of conversion efficiencies from light energy to electrical energy. The module efficiency is a measure of the percentage of solar energy converted into electricity.

Two common PV technologies that have been widely used for commercial- and utilityscale projects are crystalline silicon and thin film.

\subsubsection{Crystalline Silicon}

Traditional solar cells are made from silicon. Silicon is quite abundant and nontoxic. It builds on a strong industry on both the supply (silicon industry) and product side. This technology has been demonstrated for a consistent and high efficiency for more than 30 years in the field. The performance degradation, a reduction in power generation due to long-term exposure, is under 1\% per year. Silicon modules have a lifespan in a range of 25-30 years but can keep producing energy beyond this range. 
Typical overall efficiency of silicon solar panels is between $12 \%$ and $18 \%$. However, some manufacturers of mono-crystalline panels claim an overall efficiency nearing $20 \%$. This range of efficiencies represents significant variation among the crystalline silicon technologies available. The technology is generally divided into mono- and multicrystalline technologies, which indicates the presence of grain boundaries (i.e., multiple crystals) in the cell materials and is controlled by raw material selection and manufacturing technique. Crystalline silicon panels are widely used based on deployments worldwide.

Figure 3 shows two examples of crystalline solar panels: mono- and multi-silicon installed on tracking mounting systems.
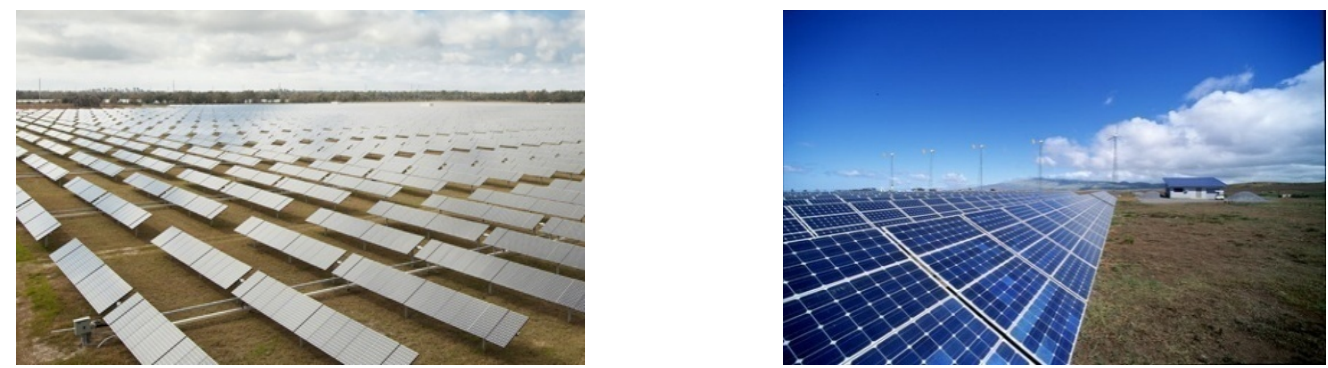

Figure 3. Mono- and multi-crystalline solar panels. Photos by (left) SunPower Corporation, NREL 23816 and (right) SunPower, NREL 13823

\subsubsection{Thin Film}

Thin-film PV cells are made from amorphous silicon (a-Si) or non-silicon materials, such as cadmium telluride (CdTe). Thin-film cells use layers of semiconductor materials only a few micrometers thick. Due to the unique nature of thin films, some thin-film cells are constructed into flexible modules, enabling such applications as solar energy covers for landfills, such as a geomembrane system. Other thin-film modules are assembled into rigid constructions that can be used in fixed-tilt or, in some cases, tracking system configurations.

The efficiency of thin-film solar cells is generally lower than for crystalline cells. Current overall efficiency of a thin-film panel is between $6 \%$ and $8 \%$ for a-Si and $11 \%$ and $12 \%$ for CdTe. Figure 4 shows thin-film solar panels.
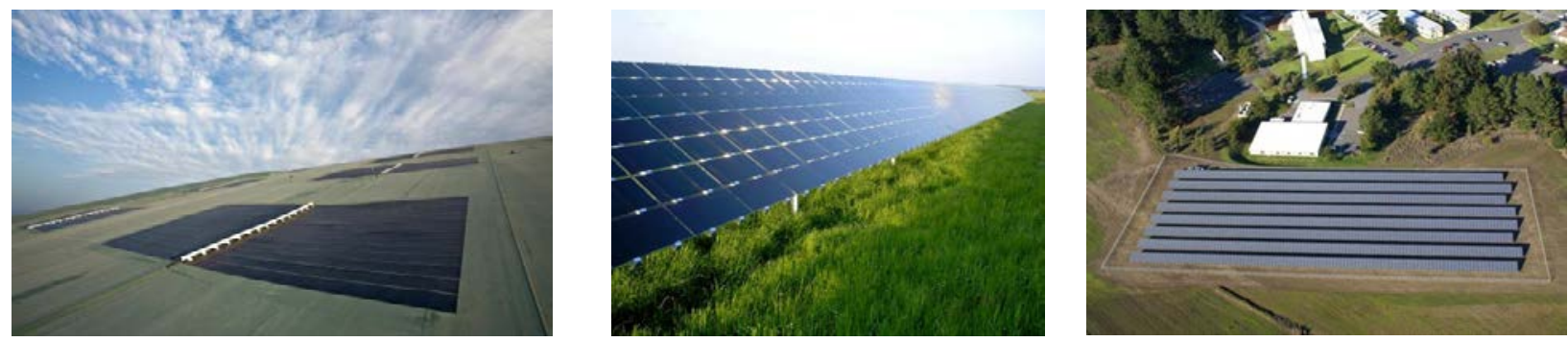

Figure 4. Thin-film solar panels installed on a (left) solar energy cover and (middle/right) fixed-tilt mounting system. Photos by (left) Republic Services, NREL 23817, (middle) Beck Energy, NREL 14726, and (right) U.S. Coast Guard Petaluma Site, NREL 17395 
Industry standard warranties of both crystalline and thin-film PV panels typically guarantee system performance of $80 \%$ of the rated power output for 25 years. After 25 years, they will continue producing electricity at a lower performance level.

\subsubsection{Inverter}

Inverters convert DC electricity from the PV array into AC and can connect seamlessly to the electricity grid. Inverter efficiencies can be as high as $98.5 \%$.

Inverters also sense the utility power frequency and synchronize the PV-produced power to that frequency. When utility power is not present, the inverter will stop producing AC power to prevent "islanding" or putting power into the grid while utility workers are trying to fix what they assume is a de-energized distribution system. This safety feature is built into all grid-connected inverters in the market. Electricity produced from the system may be fed to a step-up transformer to increase the voltage to match the grid.

There are two primary types of inverters for grid-connected systems: string and microinverters. Each type has strengths and weaknesses and would be recommended for different types of installations.

String inverters are most common and typically range in size from $1.5 \mathrm{~kW}$ to $1,000 \mathrm{~kW}$. These inverters tend to be cheaper on a capacity basis, as well as have high efficiency and lower operation and maintenance (O\&M) costs. String inverters offer various sizes and capacities to handle a large range of voltage output. For larger systems, string inverters are combined in parallel to produce a single point of interconnection with the grid. Warranties typically run between 5 and 10 years with 10 years being the current industry standard. On larger units, extended warranties up to 20 years are possible. Given that the expected life of the PV panels is 25-30 years, an operator can expect to replace a string inverter at least one time during the life of the PV system.

Micro-inverters are dedicated to the conversion of a single PV module's power output. The AC output from each module is connected in parallel to create the array. This technology is relatively new to the market and in limited use in larger systems due to the potential increase in O\&M associated with significantly increasing the number of inverters in a given array. Current micro-inverters range in size between $175 \mathrm{~W}$ and $380 \mathrm{~W}$. These inverters can be the most expensive option per watt of capacity. Warranties range from 10 to 20 years. Small projects with irregular modules and shading issues typically benefit from micro-inverters.

With string inverters, small amounts of shading on a solar panel will significantly affect the entire array production. Instead, it impacts only that shaded panel if micro-inverters are used. Figure 5 shows a string inverter. 


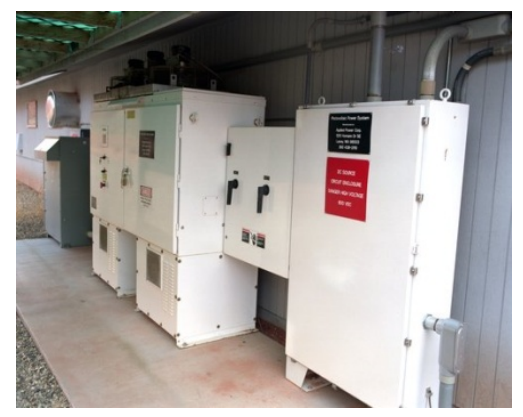

Figure 5. String inverter. Photo by Warren Gretz, NREL 07985

\subsubsection{Balance-of-System Components}

In addition to the solar modules and inverter, a solar PV system consists of other parts called BOS components, which include:

- Mounting racks and hardware for the panels

- Wiring for electrical connections.

\subsubsection{Mounting Systems}

The array has to be secured and oriented optimally to maximize system output. The structure holding the modules is referred to as the mounting system.

\subsection{Ground-Mounted Systems}

For ground-mounted systems, the mounting system can be either directly anchored into the ground (via driven piers or concrete footers) or ballasted on the surface without ground penetration. Mounting systems must withstand local wind loads, which range from 90-120 mph for most areas or $130 \mathrm{mph}$ or more for areas with hurricane potential. Depending on the region, snow and ice loads must also be a design consideration for the mounting system. For RCRA applications, mounting system designs will be primarily driven by these considerations coupled with settlement concerns.

Typical ground-mounted systems can be categorized as fixed tilt or tracking. Fixed-tilt mounting structures consist of panels installed at a set angle, typically based on site latitude and wind conditions, to increase exposure to solar radiation throughout the year. Fixed-tilt systems are used at many RCRA sites. Fixed-tilt systems have lower maintenance costs but generate less energy $(\mathrm{kWh})$ per unit power $(\mathrm{kW})$ of capacity than tracking systems.

Tracking systems rotate the PV modules so they are following the sun as it moves across the sky. This increases energy output but also increases maintenance and equipment costs slightly. Single-axis tracking, in which PV is rotated on a single axis, can increase energy output up to $25 \%$ or more. With dual-axis tracking, PV is able to directly face the sun all day, potentially increasing output up to $35 \%$ or more. Depending on underlying soiling conditions, single- and dual-axis trackers may not be suitable due to potential settlement effects, which can interfere with the alignment requirements of such systems. 
Table 1. Ground-Mounted Energy Density by Panel and System

\begin{tabular}{lcc}
\hline System Type & $\begin{array}{l}\text { Fixed-Tilt Energy Density } \\
\text { (DC-Watts/ft }\end{array}$ & $\begin{array}{l}\text { Single-Axis Tracking } \\
\text { Energy Density } \\
\text { (DC-Watts/ft }\end{array}$ \\
\cline { 2 - 3 } Crystalline Silicon & 4.0 & 3.3 \\
Thin Film & 3.3 & 2.7 \\
Hybrid High & 4.8 & 3.9 \\
Efficiency & & \\
\hline
\end{tabular}

The selection of mounting type is dependent on many factors, including installation size, electricity rates, government incentives, land constraints, latitude, and local weather. Contaminated land applications may raise additional design considerations due to site conditions, including differential settlement.

Selection of the mounting system is also heavily dependent on anchoring or foundation selection. The mounting system design will also need to meet applicable local building code requirements with respect to snow, wind, and seismic zones. Selection of mounting types should also consider frost protection needs, especially in cold regions, such as New England. The TechCity East Campus has no areas for large ground-mounted PV systems due to the high concentration of buildings on the site.

\subsection{Roof-Mounted Systems}

The TechCity East Campus has potential to use the roof area of current and future buildings for PV. Installing PV on rooftops has many of the same considerations as installing ground-mounted PV systems. Factors, such as available area for an array, solar resource, shading, distance to transmission lines, and distance to major roads at the site, are just as important in roof-mounted systems as in ground-mounted systems. Rooftop systems can be ballasted or fixed to the roof, and it is recommended that the roof be relatively new (less than 5 years old) to avoid having to move the PV system in order to repair or replace the roof.

The development plan at the TechCity East Campus has renovated existing buildings and new construction buildings. There are many relatively easy low-cost/no-cost measures that can be taken during the design phase so that the buildings are optimally built for rooftop PV systems. Design strategies, such as orienting the buildings so that the southern exposure is maximized and reducing the amount of mechanical equipment on the roof, are measures that can be taken to optimize rooftop PV systems. A solar-ready design guide was published in order to help design teams optimize rooftop PV systems when designing buildings. ${ }^{4}$

\footnotetext{
${ }^{4}$ Lisell, L.; Tetreault, T.; Watson, A. Solar Ready Buildings Planning Guide. Golden, CO: National Renewable Energy Laboratory, December 2009. Accessed October 14, 2013 :

http://www.nrel.gov/docs/fy10osti/46078.pdf.
} 
Table 2. Rooftop Energy Density by Panel

\begin{tabular}{lc}
\hline System Type & $\begin{array}{c}\text { Fixed-Tilt Energy Density } \\
\text { (DC-Watts/ft }{ }^{2} \text { ) }\end{array}$ \\
\cline { 2 - 2 } Crystalline Silicon & 10.0 \\
Thin Film & 4.3 \\
\hline
\end{tabular}

\subsubsection{Wiring for Electrical Connections}

Electrical connections, including wiring, disconnect switches, fuses, and breakers, are required to meet electrical code (e.g., NEC Article 690) for both safety and equipment protection.

In most traditional applications, wiring from (1) the arrays to inverters and (2) inverters to point of interconnection is generally run as direct burial through trenches. In RCRA applications, the wiring might be required to run through above-ground conduit due to restrictions with cap penetration or other concerns. Therefore, developers should consider noting any such restrictions, if applicable, in requests for proposals in order to improve overall bid accuracy. Similarly, it is recommended that PV system vendors reflect these costs in the quote when costing out the overall system.

\subsubsection{PV System Monitoring}

Monitoring PV systems can be essential for reliable functioning and maximum yield of a system. It can be as simple as reading values such as produced AC power, daily kilowatthours, and cumulative kilowatt-hours locally on an LCD display on the inverter. For more sophisticated monitoring and control purposes, environmental data, such as module temperature, ambient temperature, solar radiation, and wind speed, can be collected. Remote control and monitoring can be performed by various remote connections. Systems can send alerts and status messages to the control center or user. Data can be stored in the inverter's memory or in external data loggers for further system analysis. Collection of this basic information is standard for solar systems and not unique to landfill applications.

Weather stations are typically installed in large-scale systems. Weather data, such as solar radiation and temperature, can be used to predict energy production, enabling comparison of the target and actual system output and performance and identification of underperforming arrays. Operators can also use this data to identify required maintenance, shade on panels, and accumulating dirt on panels, for example. Monitoring system data can also be used for outreach and education. This can be achieved with publicly available, online displays; wall-mounted systems; or even smart phone applications.

\subsubsection{Operation and Maintenance}

PV panels typically have a 25-year performance warranty. Inverters, which come standard with a 5-year or 10-year warranty (extended warranties available), would be expected to last 10-15 years. System performance should be verified on a vendorprovided website. Wire and rack connections should be checked annually. This economic analysis uses an annual O\&M cost of $\$ 20 / \mathrm{kW} / \mathrm{year}$, which is based on the historical 
O\&M costs of installed fixed-axis grid-tied PV systems. In addition, the system should expect a replacement of system inverters in year 15 at a cost of $\$ 0.25 / \mathrm{W}$.

\subsection{Siting Considerations}

PV modules are very sensitive to shading. When shaded (either partially or fully), the panel is unable to optimally collect the high-energy beam radiation from the sun. As explained above, $\mathrm{PV}$ modules are made up of many individual cells that all produce a small amount of current and voltage. These individual cells are connected in series to produce a larger current. If an individual cell is shaded, it acts as resistance to the whole series circuit, impeding current flow and dissipating power rather than producing it.

The NREL solar assessment team uses a Solmetric SunEye solar path calculator to assess shading at particular locations by analyzing the sky view where solar panels will be located. By finding the solar access, the NREL team can determine if the area is appropriate for solar panels.

Following the successful collection of solar resource data using the Solmetric SunEye tool and determination that the site is adequate for a solar installation, an analysis to determine the ideal system size must be conducted. System size depends highly on the average energy use of the facilities on the site, PPAs, available incentives, and utility policy. 


\section{Proposed Installation Location Information}

This section summarizes the findings of the NREL solar assessment site visit on April 5, 2012.

\subsection{TechCity East Campus Site PV System}

As discussed in Section 1, the TechCity East Campus site is owned by a developer named Alan Ginsberg. IBM is responsible for the remediation at the site and for the operation of any remediation systems.

In order to get the most out of the roof area available, it is important to consider whether the layout can be improved to better incorporate a solar system. If there are unused structures that can be removed, the un-shaded area can be increased to incorporate more PV panels.

The TechCity East Campus site is approximately 138 acres and there is a high potential to build out the site with roof-mounted PV but very little potential to build out the site with ground-mounted PV due to the high concentration of buildings on the site. There are 17.5 acres $\left(762,300 \mathrm{ft}^{2}\right)$ potentially available for a roof-mounted PV system. There are currently no areas available for a ground-mounted PV system at the site. While the entire area does not need to be developed at one time due to the feasibility of staging installation as area or funding becomes available, calculations for this analysis reflect the solar potential if the total feasible area is used. It should be noted that the purpose of this report is not to determine how to develop the site but to investigate both options and present the results in an unbiased manner. Because some of the buildings are new construction, they could easily be designed to be "solar ready," even if the budget for a rooftop PV system is not available at the time of construction.

Figure 6 shows an aerial view of the potential areas for PV at the TechCity East Campus site taken from Google Earth. There is no feasible area for ground-mounted PV. The feasible area for roof-mounted PV on new construction buildings is shaded in yellow, the feasible area for roof-mounted PV on new construction parking garages is shaded in blue, and the feasible area for roof-mounted PV on existing buildings is shaded in red. As shown, there are large expanses of un-shaded roof area, which makes it a suitable candidate for roof-mounted PV. 


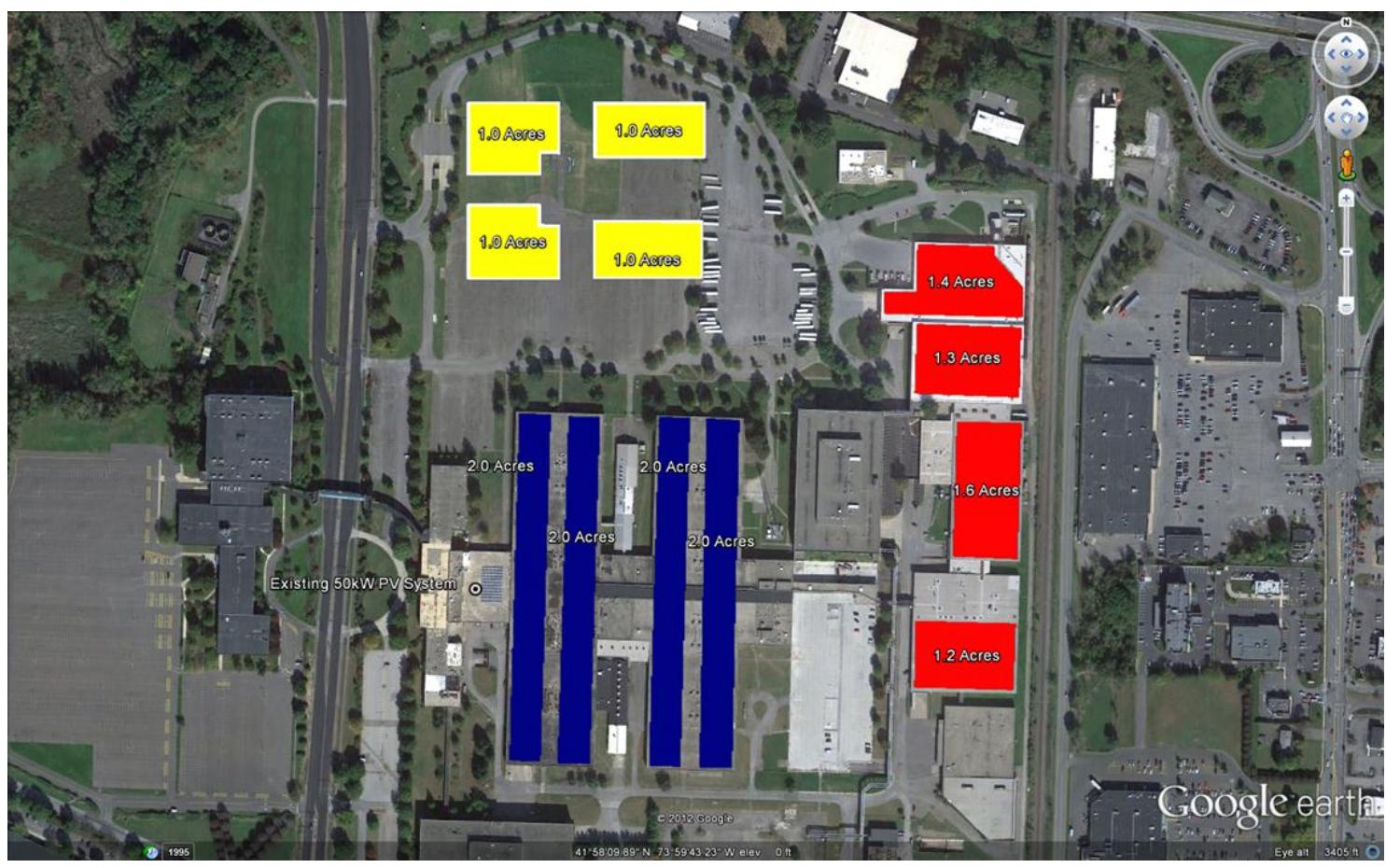

Figure 6. Aerial view of the feasible areas for PV at the Tech City East Campus

Illustration done in Google Earth

PV systems are well suited to the Kingston, New York, area, where the average global horizontal annual solar resource - the total solar radiation for a given location, including direct, diffuse, and ground-reflected radiation-is $4.48 \mathrm{kWh} / \mathrm{m}^{2} /$ day. Figure 7-Figure 9 show various views of the TechCity East Campus site where roof-mounted PV is feasible. 

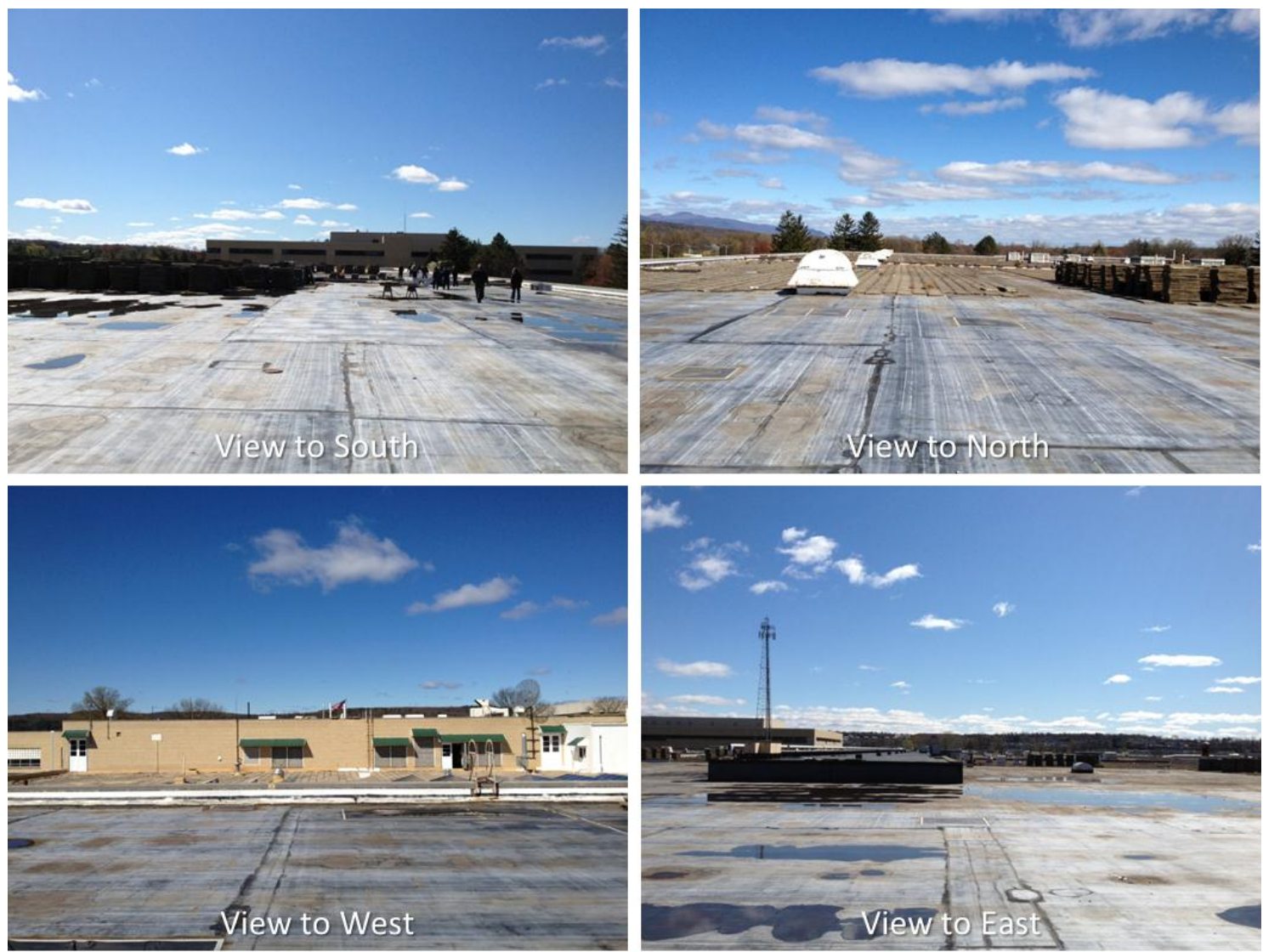

Figure 7. Views of the feasible area for roof-mounted PV on Building 1 at the TechCity East Campus. Photos by James Salasovich, NREL 

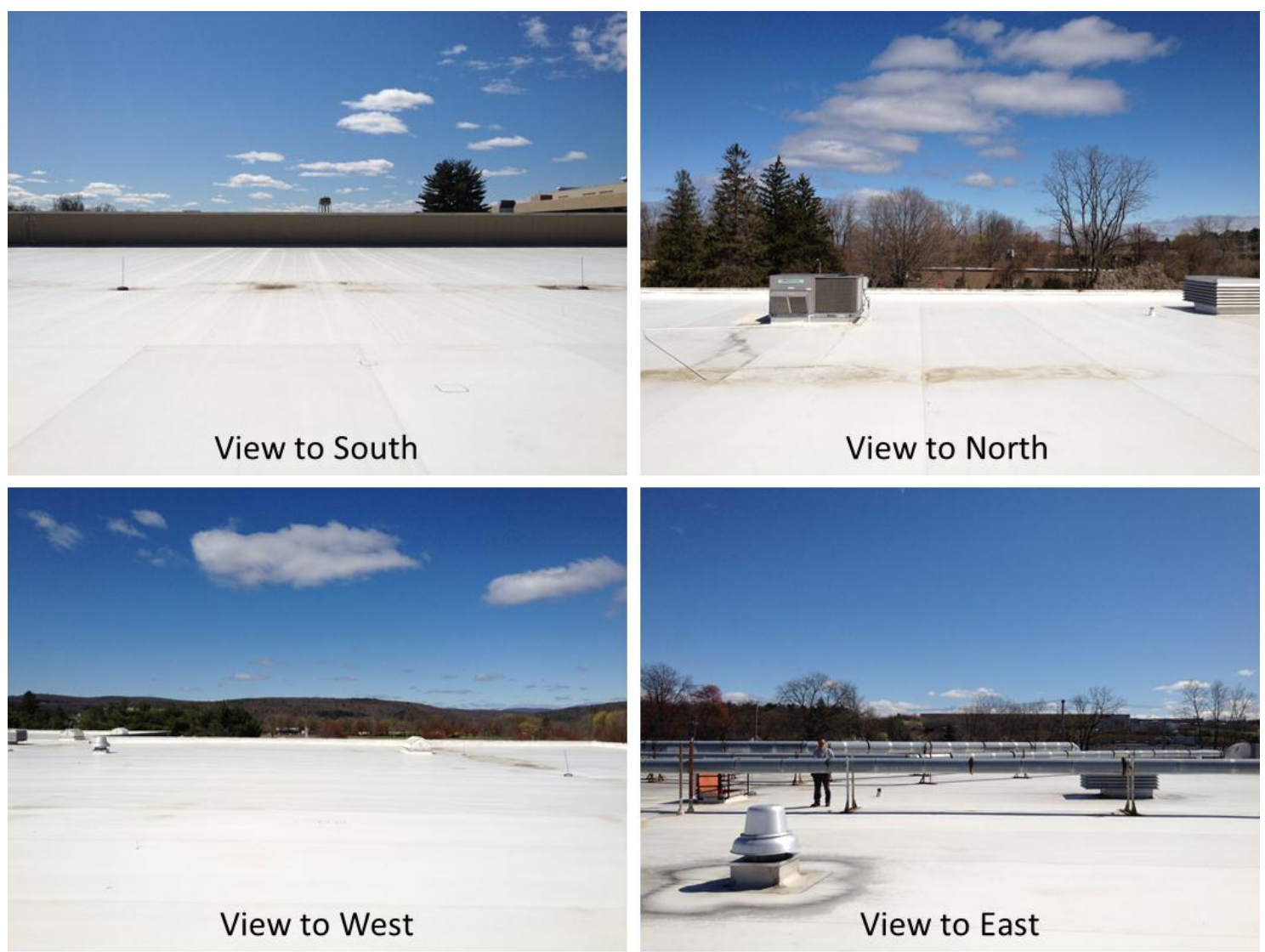

Figure 8. Views of the feasible area for roof-mounted PV on Building 52 at the TechCity East Campus. Photos by James Salasovich, NREL

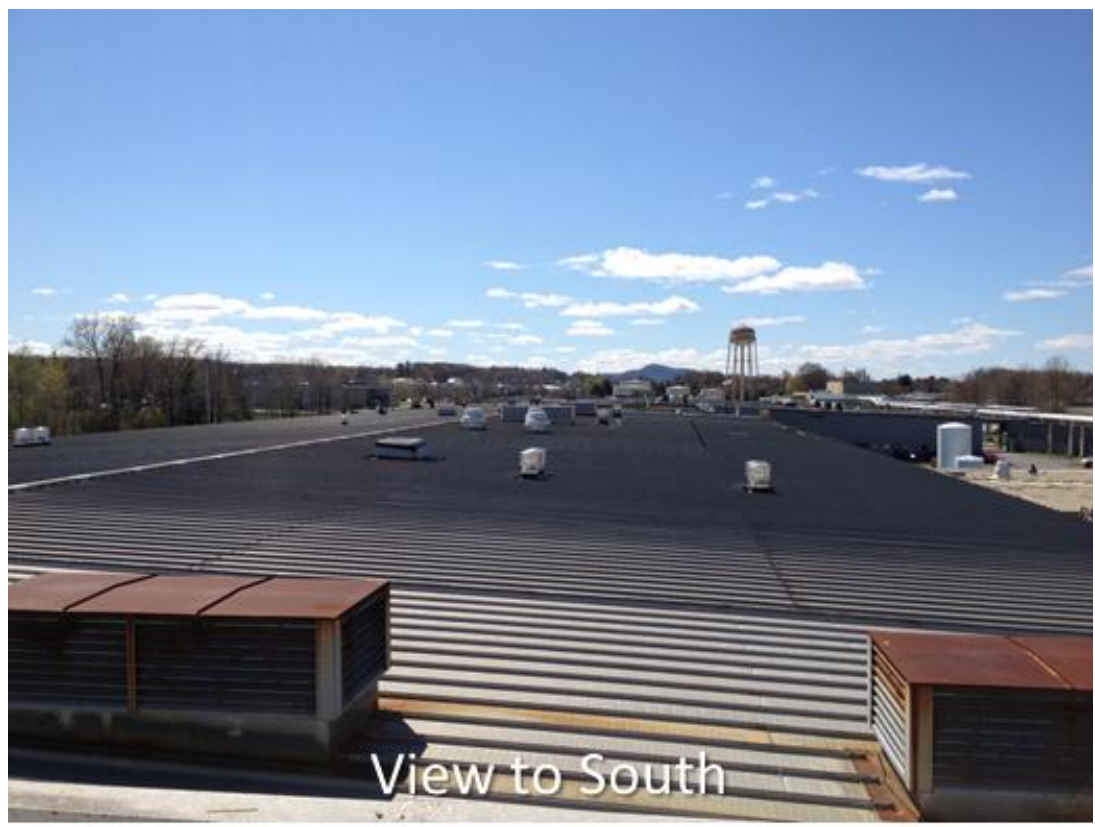

Figure 9. View of the feasible area for roof-mounted PV on Building 43 at the TechCity East Campus. Photos by James Salasovich, NREL 


\subsection{Utility-Resource Considerations}

The closest electrical tie-in location to the site is across the street at the Lincoln Park substation. Having a substation within $1,000 \mathrm{ft}$ makes it an ideal location for a PV system to tie into. A detailed interconnection study will have to be performed through the local electric utility, Central Hudson Gas \& Electric Corporation, to determine the feasibility of utilizing the onsite substation as a tie-in point for a PV system. The site currently has buildings on it, and there are new construction buildings in the future. The buildings on the site are potential off-takers of the electricity produced by a PV system.

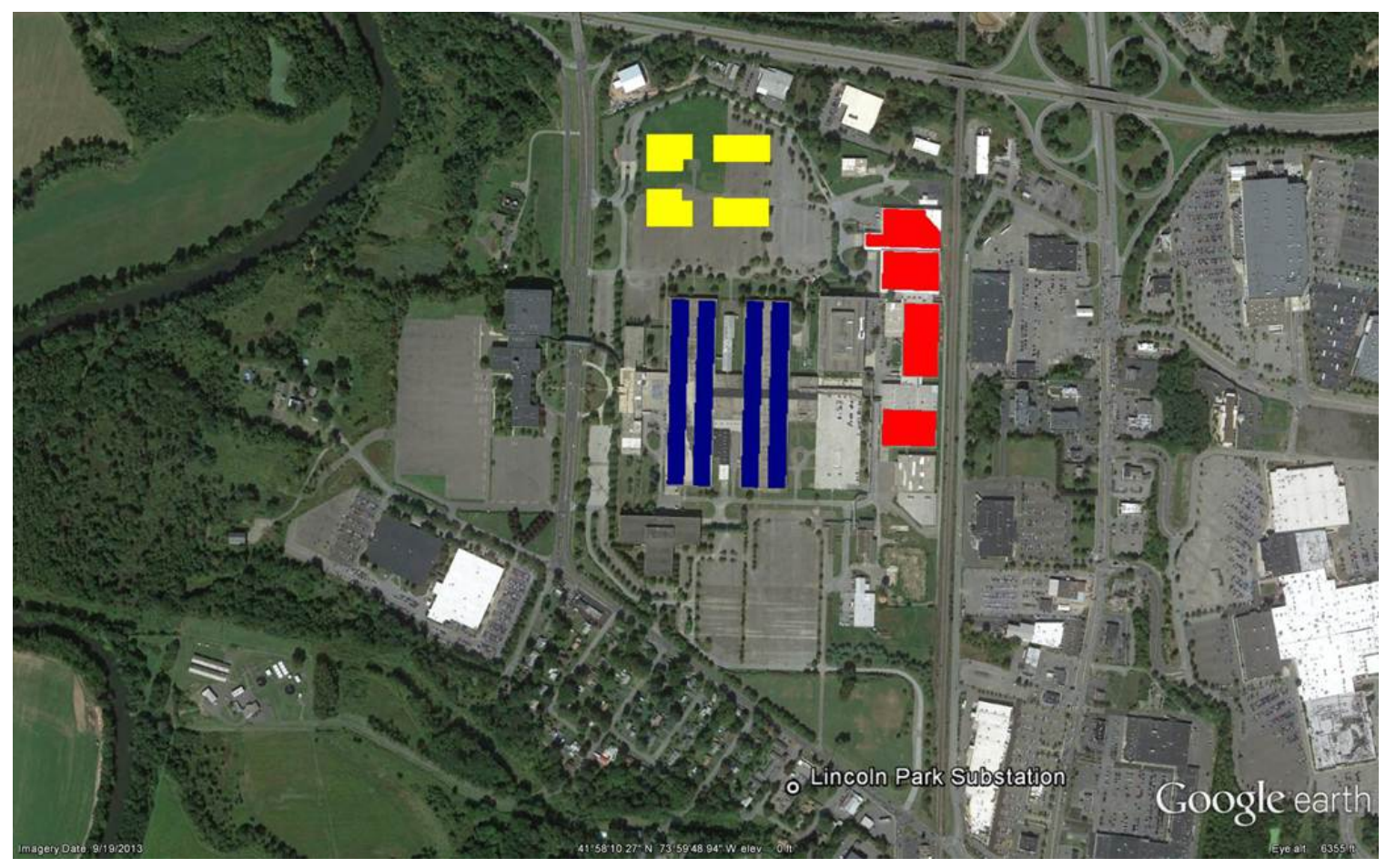

Figure 10. Location of the Lincoln Park substation in relation to the TechCity East Campus

Illustration done in Google Earth

\subsection{Useable Acreage for PV System Installation}

Typically, a minimum of 2 useable acres is recommended to site PV systems. Useable acreage is typically characterized as "flat to gently sloping" southern exposures that are free from obstructions and get full sun for at least a 6-hour period each day. For example, eligible space for PV includes under-utilized or unoccupied land, vacant lots, and/or unused paved areas (e.g., a parking lot or industrial site space), as well as existing building rooftops.

\subsection{PV Site Solar Resource}

The TechCity East Campus site has been evaluated to determine the adequacy of the solar resource available using both onsite data and industry tools. 
The assessment team for this feasibility study collected multiple Solmetric SunEye data points and found a solar access of $90 \%$ or higher. All data gathered using this tool is available in Appendix C.

The predicted array performance was found using PVWatts Version 2 for Kingston, New York. ${ }^{5}$ Table 3 shows the station identification information, PV system specifications, and energy specifications for the site. For this summary array performance information, a hypothetical system size of $1 \mathrm{~kW}$ was used to show the estimated production for each kilowatt installed. It is scaled linearly to match the proposed system size.

Table 3. Site Identification Information and Specifications

\begin{tabular}{ll}
\hline \multicolumn{2}{c}{ Station Identification } \\
\hline Cell ID & 0268367 \\
State & New York \\
Latitude & $42.0^{\circ} \mathrm{N}$ \\
Longitude & $74.1^{\circ} \mathrm{W}$ \\
\hline \multicolumn{2}{c}{ PV System Specifications } \\
DC Rating & $1.00 \mathrm{~kW}$ \\
DC to AC Derate Factor & 0.8 \\
AC Rating & $0.8 \mathrm{~kW}$ \\
Array Type & Fixed Tilt \\
Array Tilt & $20^{\circ}$ \\
Array Azimuth & South \\
\hline \multicolumn{2}{c}{ Energy Specifications } \\
Cost of Electricity & $\$ 0.0653 / \mathrm{kWh}$ \\
\hline \multicolumn{2}{c}{}
\end{tabular}

Table 4 shows the performance results for a 20-degree fixed-tilt PV system in Kingston, New York, as calculated by PVWatts.

\footnotetext{
${ }^{5}$ NREL. "PVWatts.” Accessed October 15, 2013: http://www.nrel.gov/rredc/pvwatts/.
} 
Table 4. Performance Results for 20-Degree Fixed-Tilt PV

\begin{tabular}{|c|c|c|c|}
\hline Month & $\begin{array}{l}\text { Solar Radiation } \\
\text { (kWh/m²/day) }\end{array}$ & $\begin{array}{l}\text { AC Energy } \\
\text { (kWh) }\end{array}$ & $\begin{array}{l}\text { Energy Value } \\
\text { (\$) }\end{array}$ \\
\hline 1 & 2.61 & 67 & 4.38 \\
\hline 2 & 3.49 & 81 & 5.29 \\
\hline 3 & 4.70 & 118 & 7.71 \\
\hline 4 & 5.19 & 121 & 7.90 \\
\hline 5 & 5.90 & 136 & 8.88 \\
\hline 6 & 6.13 & 133 & 8.68 \\
\hline 7 & 6.03 & 135 & 8.82 \\
\hline 8 & 5.70 & 127 & 8.29 \\
\hline 9 & 5.13 & 114 & 7.44 \\
\hline 10 & 3.90 & 93 & 6.07 \\
\hline 11 & 2.65 & 62 & 4.05 \\
\hline 12 & 2.23 & 56 & 3.66 \\
\hline Year & 4.48 & 1243 & 81.17 \\
\hline
\end{tabular}

\subsection{TechCity East Campus Energy Usage}

The TechCity East Campus site currently has buildings on the site that use electricity. There are future plans to build a significant number of buildings on the site. It is important to understand the energy use of the site to enable for a full analysis of whether or not energy produced would need to be sold or if it could offset onsite energy use.

\subsubsection{Current Energy Use}

There are currently buildings on the site that use electricity. No monthly current electricity usage or cost data was available for the site, but the current annual electricity use is estimated at $800,000 \mathrm{kWh} / \mathrm{month}$.

\subsubsection{Net Metering}

Net metering is an electricity policy for consumers who own renewable energy facilities. "Net," in this context, is used to mean "what remains after deductions"—in this case, the deduction of any energy outflows from metered energy inflows. Under net metering, a system owner receives retail credit for at least a portion of the electricity it generates. As part of the Energy Policy Act of 2005, under Sec. 1251, all public electric utilities are required upon request to make net metering available to their customers:

(11) NET METERING.-Each electric utility shall make available upon request net metering service to any electric consumer that the electric utility serves. For purposes of this paragraph, the term 'net metering service' means service to an electric consumer under which electric energy generated by that electric consumer from an eligible on-site generating facility and delivered to the local distribution facilities may be used to offset electric energy provided by the electric utility to the electric consumer during the applicable billing period.

New York's net-metering law, which began in 1997, requires that an investor-owned utility offer net metering for all customers of up to $1 \%$ of the utility's 2005 total aggregate demand. 
New York does not allow any new or additional demand charges, standby charges, customer charges, minimum monthly charges, interconnection charges, or other charges that would increase an eligible customer-generator's costs beyond those of other customers in the rate class to which the eligible customer-generator would otherwise be assigned. The New York Department of Public Service has explicitly ruled that technologies eligible for net metering (up to $2 \mathrm{MW}$ ) are exempt from interconnection application fees, as well as from initial and supplemental interconnection review fees.

Any net excess generation (NEG) in a 12-month period is carried forward into the next 12-month cycle.

\subsubsection{Virtual Net Metering}

Some states and utilities allow for virtual net metering (VNM). This arrangement can allow certain entities, such as a local government, to install renewable generation of up to a 1-MW limit at one location within its geographic boundary and to generate credits that can be used to offset charges at one or more other locations within the same geographic boundary. New York currently does not offer VNM to PV generators. 


\section{Economics and Performance}

The economic performance of a PV system installed on the site is evaluated using a combination of the assumptions and background information discussed previously as well as a number of industry-specific inputs determined by other studies. In particular, this study uses the NREL System Advisor Model (SAM). ${ }^{6}$

SAM is a performance and economic model designed to facilitate decision making for people involved in the renewable energy industry, ranging from project managers and engineers to incentive program designers, technology developers, and researchers.

SAM makes performance predictions for grid-connected solar, solar water heating, wind, and geothermal power systems and makes economic calculations for both projects that buy and sell power at retail rates and power projects that sell power through a PPA. SAM calculates the cost of generating electricity based on information you provide about a project's location, installation and operating costs, type of financing, applicable tax credits and incentives, and system specifications.

SAM consists of a performance model and financial model. The performance model calculates a system's energy output on an hourly basis (sub-hourly simulations are available for some technologies). The financial model calculates annual project cash flows over a period of years for a range of financing structures for residential, commercial, and utility projects.

\subsection{Assumptions and Input Data for Analysis}

The cost of a PV system depends on the system size and other factors, such as geographic location, mounting structure, and type of PV module. Based on significant cost reductions seen in 2011, the average cost for utility-scale ground-mounted systems have declined from $\$ 4.80 / \mathrm{W}$ in the first quarter of 2010 to $\$ 2.79 / \mathrm{W}$ in the first quarter of 2012 . With an increasing demand and supply, potential of further cost reduction is expected as market conditions evolve.

For this analysis the installed cost of the baseline fixed-tilt roof-mounted systems was assumed to be $\$ 2.79 / \mathrm{W}$. This price includes the PV array and the BOS components for each system, including the inverter and electrical equipment, as well as the installation cost. This includes estimated taxes and a national-average labor rate but does not include land cost. The economics of grid-tied PV depend on incentives, the cost of electricity, the solar resource, and panel tilt and orientation.

Single-axis tracking systems were not included in this analysis. The site does not have enough space to make use of any ground-mounted systems, and single-axis tracking systems are not installed on roofs.

TechCity is expected to get electricity service from Gateway Energy and supplied by Central Hudson Gas \& Electric. The utility retail rate used in the economic analysis is $\$ 0.0653 / \mathrm{kWh}$ with a $\$ 6.65 / \mathrm{kW}$ demand charge. This rate is based upon Central Hudson's S.C No. 2 base delivery

\footnotetext{
${ }^{6}$ For additional information on the SAM, see https://sam.nrel.gov/cost.
} 
rate of $\$ 0.00148 / \mathrm{kWh}$ and demand charge of $\$ 6.65 / \mathrm{kW}^{7}$ and Central Hudson's average supply charge of $\$ 0.0638 / \mathrm{kWh}$ for the past year. ${ }^{8}$ This number is a fair representation of the local utility market and not expected to be the actual rate attained by TechCity, as utility service contracts can be negotiated.

It was assumed for this analysis that relevant federal and state incentives are received for taxable entities. It is important to consider all applicable incentives or grants to make PV as cost effective as possible. The full list of incentives used in this study can be found on Table 5. The net-metering program was only applied to the $2,000-\mathrm{kW}$ system case.

Table 5. Summary of Incentives Evaluated

\begin{tabular}{|c|c|c|}
\hline Incentive Title & Modeled Value & Expected End \\
\hline 1. PV Incentive Program & $\$ 1.5 / \mathrm{W}, \$ 75,000$ cap & $12 / 31 / 2015$ \\
\hline 2. Federal Investment Tax Credit & $30 \%$ of total investment & 2016 \\
\hline 3. Net Metering & Net meter up to $2 \mathrm{MW}$ & - \\
\hline 4. Sales Tax Exemption & $0 \%$ sales tax & - \\
\hline 5. Property Tax Incentive & $100 \%$ of assessed value & - \\
\hline
\end{tabular}

For the purposes of this analysis, the project is expected to have a 25 -year life, although the systems can reasonably be expected to continue operation past this point. A full list of standard assumptions can be found in Appendix B. For the purposes of modeling how much PV could cover rooftops and spaces onsite, it was assumed that $80 \%$ of the land space could contain PV. PVWatts Version 2 was used to calculate expected energy performance for the system.

\subsection{SAM-Forecasted Economic Performance}

Using varied inputs and the assumptions summarized in Section 5.1, SAM predicts net present value (NPV), PPA, and levelized cost of energy (LCOE). Five scenarios total were run for the TechCity East Campus. The site has enough rooftop space available for PV development of a 6.76-MW system. This maximum system was modeled with two cases, splitting up the flat (0-degree tilt) and tilted panels. Three net-metering cases were run to determine the results for a maximum net-metering case at $2 \mathrm{MW}$, a breakeven PV array size at $85 \mathrm{~kW}$, and the best economic case for TechCity at $50 \mathrm{~kW}$. There are multiple factors that go into choosing a scenario(s) beyond NPV, PPA, and LCOE; however, Table 6 shows the results from the different options mentioned above.

\footnotetext{
${ }^{7}$ Central Hudson Gas \& Electric Corporation. "Re: Cases 09-E-0588/09-G-0589 Compliance Filing Changes." Accessed October 15, 2013: http://www.cenhud.com/pdf/ratesummary09.pdf.

${ }^{8}$ Central Hudson Gas \& Electric Corporation. "Energy Choice." Accessed October 15, 2013: http://www.centralhudson.com/energy_choice/price_history.html.
} 
Table 6. Summary of SAM Results

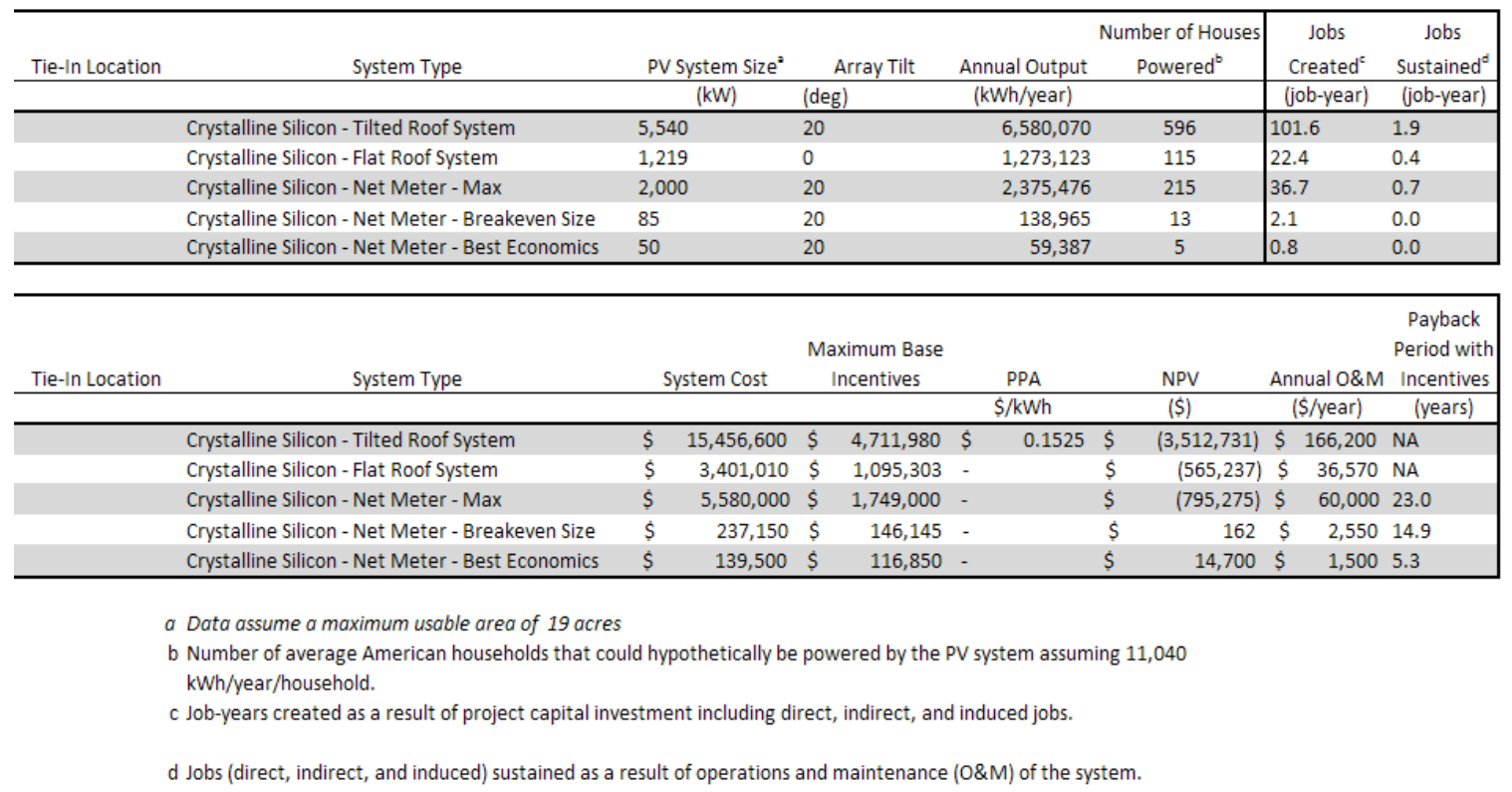

The best economic case for the TechCity campus is the $50-\mathrm{kW}$ PV array, which is sized to the maximum incentive available through the New York PV Investment Program-\$75,000. This increases the portion of the system cost reimbursed through incentives to over $80 \%$, excluding tax exemptions. The breakeven case represents the maximum size PV array that could be built before the economics of the system become unfavorable. Any system between $50 \mathrm{~kW}$ and $161 \mathrm{~kW}$ are expected to be economically favorable under current conditions. For the entire system build out models, the tilted panels are more economical than the flat panels but both maxed size systems are not currently economic. With improved incentives the site could take further advantage of the net-metering policy and with enough incentive utilizing the entire roof space for a PV system is possible. Further analysis should be performed around the site to determine exact levels of funding that would incite investment.

\subsubsection{Solar Investor Versus Developer Owned}

The choice between going with a solar investor or developer ownership will depend on the desire for involvement and the risk appetite of the developer. While ownership of the system will bring a higher payback for the developer, it will also require hiring the contractors to permit, install, and maintain the system. A solar investor inherits that risk and profit, and the TechCity East Campus in turn will receive power from the PV system at a rate determined by the investor. The recommendation of the feasibility team is to not pursue a PPA because the PPA is much higher than the current utility price. If a PPA was pursued, the tilted PV panels are recommended because that system is modeled to be slightly cheaper than including the flat panels. The predicted price is $\$ 0.1525 / \mathrm{kWh}$.

\subsubsection{Possible Ways to Improve the Economics Not Modeled}

The economics for a PV system at the TechCity East Campus could be feasible under a much lower installed price or much higher electricity prices. The breakeven installation price for the 
full net-metering case is $\$ 2.15 / \mathrm{W}$. Likewise, if the annual cost of energy were to increase to $\$ 0.106 / \mathrm{kWh}$, the full 2-MW net-meter cases would become economically feasible. Under that utility electricity cost scenario, the NPV of the $2 \mathrm{MW}$ would be $\$ 4,348$ and have a payback of 14.4 years.

The entire results and summary of inputs to SAM is available in Appendix E.

\subsection{Job Analysis and Impact}

To evaluate the employment and economic impacts of the PV project associated with this analysis, the NREL Jobs and Economic Development Impact (JEDI) models are used. ${ }^{9}$ JEDI estimates the economic impacts associated with the construction and operation of distributed generation power plants. It is a flexible input-output tool that estimates, but does not precisely predict, the number of jobs and economic impacts that can be reasonably supported by the proposed facility.

JEDI represents the entire economy, including cross-industry or cross-company impacts. For example, JEDI estimates the impact that the installation of a distributed generation facility would have on not only the manufacturers of PV modules and inverters but also the associated construction materials, metal fabrication industry, project management support, transportation, and other industries that are required to enable the procurement and installation of the complete system.

For this analysis, inputs, including the estimated installed project cost $(\$ / \mathrm{kW})$, targeted year of construction, system capacity $(\mathrm{kW}), \mathrm{O} \& \mathrm{M}$ costs $(\$ / \mathrm{kW})$, and location, were entered into the model to predict the jobs and economic impacts. It is important to note that JEDI does not predict or incorporate any displacement of related economic activity or alternative jobs due to the implementation of the proposed project. As such, the JEDI results are considered gross estimates as opposed to net estimates.

Table 7 shows the assumed values for the TechCity East Campus site.

Table 7. JEDI Analysis Assumptions

\begin{tabular}{ll}
\hline Input & Assumed Value \\
\cline { 2 - 2 } Capacity & $161 \mathrm{~kW}$ \\
Placed In Service Year & 2013 \\
Installed System Cost & $\$ 449,190$ \\
Location & Kingston, NY \\
\hline
\end{tabular}

Using the assumptions from Table 7, JEDI estimates the gross direct and indirect jobs, associated earnings, and total economic impact supported by the construction and continued operation of the proposed PV system

\footnotetext{
${ }^{9}$ JEDI has been used by the U.S. Department of Energy, the U.S. Department of Agriculture, NREL, and the Lawrence Berkeley National Laboratory, as well as a number of universities. For information on JEDI, see http://www.nrel.gov/analysis/jedi/about_jedi.html.
} 
The estimates of jobs associated with this project are presented as either construction-period jobs or sustained-operations jobs. Each job is expressed as a whole, or fraction, full-time equivalent (FTE) position. An FTE is defined as 40 hours per week for one person for the duration of a year. Construction-period jobs are considered short-term positions that exist only during the procurement and construction periods.

As indicated in the results of the JEDI analysis provided in Appendix D, the total proposed system is estimated to support 3.0 direct and indirect jobs per year for the duration of the procurement and construction periods. Total wages paid to workers during the construction period are estimated to be $\$ 172,400$, and total economic output is estimated to be $\$ 418,700$. The annual O\&M of the new PV system is estimated to support 0.1 FTEs per year for the life of the system. The jobs and associated spending are projected to account for approximately $\$ 3,500$ in earnings and $\$ 6,000$ in economic activity each year for the next 25 years.

\subsection{Financing Opportunities}

The procurement, development, construction, and management of a successful utility-scale distributed generation facility can be owned and financed a number of different ways. The most common ownership and financing structures are described below.

\subsubsection{Owner and Operator Financing}

The owner/operator financing structure is characterized by a single entity with the financial strength to fund all of the solar project costs and, if a private entity, sufficient tax appetite to utilize all of the project's tax benefits. Private owners/operators typically establish a special purpose entity (SPE) that solely owns the assets of the project. An initial equity investment into the SPE is funded by the private entity using existing funds and all of the project's cash flows and tax benefits are utilized by the entity. This equity investment is typically matched with debt financing for the majority of the project costs. Project debt is typically issued as a loan based on the owners' and operators' assets and equity in the project. In addition, private entities can utilize any of the federal tax credits offered.

For public entities that choose to finance, own, and operate a solar project, funding can be raised as part of a larger, general obligation bond; as a standalone tax credit bond; through a tax-exempt lease structure, bank financing, grant and incentive program, or internal cash; or some combination of the above. Certain structures are more common than others and grant programs for solar programs are on the decline. Regardless, as tax-exempt entities, public entities are unable to benefit directly from the various tax-credit-based incentives available to private companies. This has given way to the now common use of third-party financing structures, such as the PPA.

\subsubsection{Third-Party Developers With Power Purchase Agreements}

Because many project site hosts do not have the financial or technical capabilities to develop a capital-intensive project, many times they turn to third-party developers (and/or their investors). In exchange for access to a site through a lease or easement arrangement, third-party developers will finance, develop, own, and operate solar projects utilizing their own expertise and sources of tax equity financing and debt capital. Once the system is installed, the third-party developer will sell the electricity to the site host or local utility via a PPA — a contract to sell electricity at a 
negotiated rate over a fixed period of time. The PPA typically will be between the third-party developer and the site host if it is a retail "behind-the-meter" transaction or directly with an electric utility if it is a wholesale transaction.

Site hosts benefit by either receiving competitively priced electricity from the project via the PPA or land lease revenues for making the site available to the solar developer via a lease payment. This lease payment can take on the form of either a revenue-sharing agreement or an annual lease payment. In addition, third-party developers are able to utilize federal tax credits. For public entities, this arrangement allows them to utilize the benefits of the tax credits (low PPA price, higher lease payment) while not directly receiving them. The term of a PPA typically varies from 20-25 years.

\subsubsection{Third-Party "Flip" Agreements}

The most common use of this model is a site host working with a third-party developer who then partners with a tax-motivated investor in an SPE that would own and operate the project. Initially, most of the equity provided to the SPE would come from the tax investor and most of the benefit would flow to the tax investor (as much as 99\%). When the tax investor has fully monetized the tax benefits and achieved an agreed-upon rate of return, the allocation of benefits and majority ownership (95\%) would "flip" to the site host (but not within the first 5 years). After the flip, the site host would have the option to buy out all or most of the tax investor's interest in the project at fair market value of the tax investor's remaining interest.

A "flip" agreement can also be signed between a developer and investors within an SPE, where the investor would begin with the majority ownership. Eventually, the ownership would flip to the developer once each investor's return is met.

\subsubsection{Hybrid Financial Structures}

As the solar market evolves, hybrid financial solutions have been developed in certain instances to finance solar projects. A particular structure, nicknamed "The Morris Model" after Morris County, New Jersey, combines highly rated public debt, a capital lease, and a PPA. Low-interest public debt replaces more costly financing available to the solar developer and contributes to a very attractive PPA price for the site hosts. New markets tax credits have been combined with PPAs and public debt in other locations, such as Denver and Salt Lake City.

\subsubsection{Solar Services Agreement and Operating Lease}

The solar services agreement (SSA) and operating lease business models have been predominately used in the municipal and cooperative utility markets due their treatment of tax benefits and the rules limiting federal tax benefit transfers from non-profit to for-profit companies. Under IRS guidelines, municipalities cannot enter capital leases with for-profit entities when the for-profit entities capture tax incentives. As a result, a number of business models have emerged as a work-around to this issue. One model is the SSA wherein a private party sells "solar services" (i.e., energy and renewable energy certificates [RECs]) to a municipality over a specified contract period (typically long enough for the private party to accrue the tax credits). The non-profit utility typically purchases the solar services with either a one-time up-front payment equal to the turn-key system cost minus the $30 \%$ federal tax credit or in annual installments. The municipality can buy out the system once the third party has accrued 
the tax credits, but due to IRS regulations, the buyout of the plant cannot be included as part of the SSA (i.e., the SSA cannot be used as a vehicle for a sale and must be a separate transaction).

Similar to the SSA, there are a variety of lease options that are available to municipalities that allow the capture of tax benefits by third-party owners, which result in a lower cost to the municipality. These include an operating lease for solar services (as opposed to an equipment capital lease) and a complex business model called a "sales/leaseback."

\subsubsection{Sales/Leaseback}

Under the sales/leaseback model, the municipality develops the project and sells it to a thirdparty tax equity investor who then leases the project back to the municipality under an operating lease. At the end of the lease period, and after the tax benefits have been absorbed by the tax equity investor, the municipality can purchase the solar project at fair market value. The lessee would be responsible for operating and maintaining the solar system as well as have the right to sell or use the power. In exchange for use of the solar system, the public or private entity would make lease payments to the tax investor (the lessor). The tax investor would have rights to federal tax benefits generated by the project and the lease payments.

\subsubsection{Community Solar Gardens}

The concept of "community solar" is one in which the costs and benefits of one large solar project are shared by a number of participants. A site owner may be able to make land available for a large solar project, which can be the basis for a community solar project. Ownership structures for these projects vary, but the large projects are typically owned or sponsored by a local utility.

Community solar gardens are distributed solar projects wherein utility customers have a stake via a pro-rated share of the project's energy output. This business model is targeted to meet demand for solar projects by customers who rent/lease homes or businesses, do not have good solar access at their site, or do not want to install a solar system on their facilities. Customer pro-rated shares of solar projects are acquired through a long-term transferrable lease of one or more panels, or they subscribe to a share of the project in terms of a specific level of energy output or the energy output of a set amount of capacity. Under the customer lease option, the customer receives a billing credit for the number of kilowatt-hours their pro-rated share of the solar project produces each month; it is also known as VNM. Under the customer subscription option, the customers typically pay a set price for a block of solar energy (i.e., $100 \mathrm{kWh}$ per month blocks) from the community solar project. Other models include monthly energy outputs from a specific investment dollar amount or a specific number of panels.

Community solar garden and customer subscription-based projects can be owned solely by the utility, owned solely by third-party developers with facilitation of billing provided by the utility, or be a joint venture between the utility and a third-party developer leading to eventual ownership by the utility after the tax benefits have been absorbed by the third-party developer.

There are some states that offer solar incentives for community solar projects, including Washington State (production incentive) and Utah (state income tax credit). Community solar is known as solar gardens depending on the location (e.g., Colorado). 


\section{Conclusions and Recommendations}

The inclusion of a small PV array is currently an economically viable option, but small changes in policy, PV cost, or electricity could make the full net-metering case viable. With these changes, a larger system could be feasible in the near future.

Installing the 85-kW PV system on the TechCity East Campus could generate 138,965 kWh annually. As summarized in Section 5, the SAM economic analysis predicts the best NPV and LCOE of $\$ 24,498$ and less than $\$ 0.0297 / \mathrm{kWh}$, respectively, for the 50-kW net-metering case. In a solar investor/PPA case for the entire 5,540-kW PV buildout, the PPA price is modeled to be $\$ 0.1525 / \mathrm{kWh}$.

The site has enough rooftop space available for PV development of a 6.76-MW system. This system would produce 3,926 MWh of energy annually - enough to power 711 homes. The economics for a larger PV system at the TechCity East Campus could be feasible under lower installed prices, higher electricity prices, or incentives from policies. The breakeven price for the net-metering case ( $2 \mathrm{MW}$ is the max net metering size) is $\$ 2.15 / \mathrm{W}$. Likewise, if the price for electricity were to increase to $\$ 0.106 / \mathrm{kWh}$, both of the net-metering cases (the $2 \mathrm{MW}$ and slightly smaller 1.2MW) would become economically feasible.

Following completion of the feasibility study, the RE-Powering team identified a potential funding source to improve project economics for large-scale solar systems at the former TechCity site. As part of the NY-Sun Initiative, the New York State Energy Research and Development Authority (NYSERDA) is accepting applications for solar projects that are $50 \mathrm{~kW}$ or more. Through a state-side competitive bidding process, NYSERDA plans to provide performance-based incentives on a dollar-per-kilowatt-hour basis. This type of incentive program may improve project economics sufficiently for the deployment of large-scale systems (2-5 MW) at the TechCity site.

A preliminary analysis shows an incentive over a 3-year period of $\$ 0.087 / \mathrm{kWh}$ for a $2-\mathrm{MW}$ system or $\$ 0.195 / \mathrm{kWh}$ for a $5-\mathrm{MW}$ system could provide sufficient returns, in the case where the incentive is not taxable. If taxed, the incentives required for breakeven would increase to $\$ 0.150 / \mathrm{kWh}$ and $\$ 0.332 / \mathrm{kWh}$, respectively.

While the cost of solar energy installations has decreased significantly in recent years, incentives at the federal, state, and/or local level are typically required to be competitive with conventional fuel sources or provide sufficient returns for investors. To achieve the site owner's vision for a utility-scale rooftop system, use of state incentives, such as the NY-Sun Initiative, will likely be required for near-term development. 


\section{Appendix A. Assessment and Calculations Assumptions}

Table A-1. Cost, System, and Other Assessment Assumptions

\begin{tabular}{lccl}
\hline $\begin{array}{l}\text { Cost Assumptions } \\
\text { Variable }\end{array}$ & $\begin{array}{l}\text { Quantity of } \\
\text { Variable }\end{array}$ & Unit of Variable & \\
\hline $\begin{array}{l}\text { Cost of Site Electricity } \\
\text { Annual O\&M (fixed) }\end{array}$ & 0.0653 & $\begin{array}{l}\$ / \mathrm{kWh} \\
\$ / \mathrm{kW} / \mathrm{year}\end{array}$ & \\
\hline $\begin{array}{l}\text { System Assumptions } \\
\text { System Type }\end{array}$ & 20 & & \\
& $\begin{array}{l}\text { Annual energy } \\
\text { kWh/kW }\end{array}$ & $\begin{array}{l}\text { Installed Cost } \\
\mathbf{( \$ / W )}\end{array}$ & $\begin{array}{l}\text { Energy Density } \\
\text { (W/sq. ft.) }\end{array}$ \\
\hline Roof Fixed & 1,243 & $\$ 2.79$ & 4.00 \\
\hline Other Assumptions & 1 acre & $43,560 \mathrm{ft}^{2}$ & \\
& $1 \mathrm{MW}$ & $1,000,000 \mathrm{~W}$ & \\
& Ground & $\begin{array}{l}\text { 90\% of available } \\
\text { area }\end{array}$ & \\
\hline
\end{tabular}


Table A-2. Cost, System, and Other Assessment Assumptions

\begin{tabular}{|c|c|c|c|}
\hline Item & PPA/Investor & $\begin{array}{l}\text { Municipal } \\
\text { Purchase }\end{array}$ & Notes \\
\hline $\begin{array}{l}\text { Analysis period } \\
\text { (years) }\end{array}$ & 25 & 25 & \\
\hline Inflation & $2.50 \%$ & $2.50 \%$ & \\
\hline Real discount rate & $5.85 \%$ & $3 \%$ & \\
\hline Federal tax rate & $35 \%$ & $0 \%$ & \\
\hline State tax rate & $8 \%$ & $0 \%$ & \\
\hline $\begin{array}{l}\text { Insurance (\% of } \\
\text { installed cost) }\end{array}$ & $0.50 \%$ & $0.50 \%$ & \\
\hline Property tax & 0 & 0 & \\
\hline Construction loan & 0 & 0 & \\
\hline Loan term & 15 & 25 & 25-year bonds \\
\hline Loan rate & $6 \%$ & $6 \%$ & May be lower for bonds \\
\hline Debt fraction & $55 \%$ & $100 \%$ & $\begin{array}{r}45 \%-60 \% \text { PPA, } 100 \% \\
\text { municipal ownership, DSCR of } \\
\sim 1.3(>1.2) \\
\end{array}$ \\
\hline $\begin{array}{l}\text { Minimum internal } \\
\text { rate of return }\end{array}$ & $15.00 \%$ & $15.00 \%$ & \\
\hline $\begin{array}{l}\text { PPA escalation } \\
\text { rate }\end{array}$ & $1.50 \%$ & $1.50 \%$ & \\
\hline $\begin{array}{l}\text { Federal } \\
\text { depreciation }\end{array}$ & $\begin{array}{l}5 \text {-year MACRS w/ } \\
50 \% \text { first-year } \\
\text { bonus }\end{array}$ & $\mathrm{N} / \mathrm{A}$ & N/A for municipal ownership \\
\hline State depreciation & 5-year MACRS & $\mathrm{N} / \mathrm{A}$ & N/A for municipal ownership \\
\hline $\begin{array}{l}\text { Federal } \\
\text { investment tax } \\
\text { credit }\end{array}$ & $30 \%$ & $\mathrm{~N} / \mathrm{A}$ & N/A for municipal ownership \\
\hline $\begin{array}{l}\text { Payment } \\
\text { incentives }\end{array}$ & 0 & 0 & \\
\hline Degradation & $0.50 \%$ & $0.50 \%$ & \\
\hline Availability & $100 \%$ & $100 \%$ & \\
\hline $\begin{array}{l}\text { Cost - fixed axis } \\
\text { per kW }\end{array}$ & $\$ 2.79-\$ 3.20$ & $\$ 2.79-\$ 3.20$ & \\
\hline $\begin{array}{l}\text { Cost - single-axis } \\
\text { tracking per kW }\end{array}$ & $\$ 3.35-\$ 3.84$ & $\$ 3.35-\$ 3.84$ & \\
\hline $\begin{array}{l}\text { Cost - landfill } \\
\text { ballasted per kW }\end{array}$ & $\$ 3.49-\$ 4.00$ & $\$ 3.49-\$ 4.00$ & \\
\hline $\begin{array}{l}\text { Grid } \\
\text { interconnection } \\
\text { cost }\end{array}$ & $\$$ & $\$$ & \\
\hline Land cost & $\$$ & $\$$ & \\
\hline
\end{tabular}




\begin{tabular}{|c|c|c|}
\hline O\&M & $\begin{array}{l}\$ 30 / \mathrm{kW} / \mathrm{yr} \text { first } 15 \\
\text { yrs and } \$ 20 / \mathrm{kW} / \mathrm{yr} \\
\text { yrs } 16-25\end{array}$ & $\begin{array}{l}\$ 30 / \mathrm{kW} / \mathrm{yr} \text { first } 15 \\
\text { yrs and } \$ 20 / \mathrm{kW} / \mathrm{yr} \\
\text { yrs } 16-26\end{array}$ \\
\hline Derate factor & 0.8 & 0.8 \\
\hline Fixed tilt & $20^{\circ}$ & $20^{\circ}$ \\
\hline Single-axis tilt & $0^{\circ}$ & $0^{\circ}$ \\
\hline $\begin{array}{l}\text { Acres per MW } \\
\text { fixed }\end{array}$ & 5.74 & 5.74 \\
\hline $\begin{array}{l}\text { Acres per MW } \\
\text { tracking }\end{array}$ & 6.96 & 6.96 \\
\hline
\end{tabular}




\section{Appendix B. Results of the System Advisor Model}

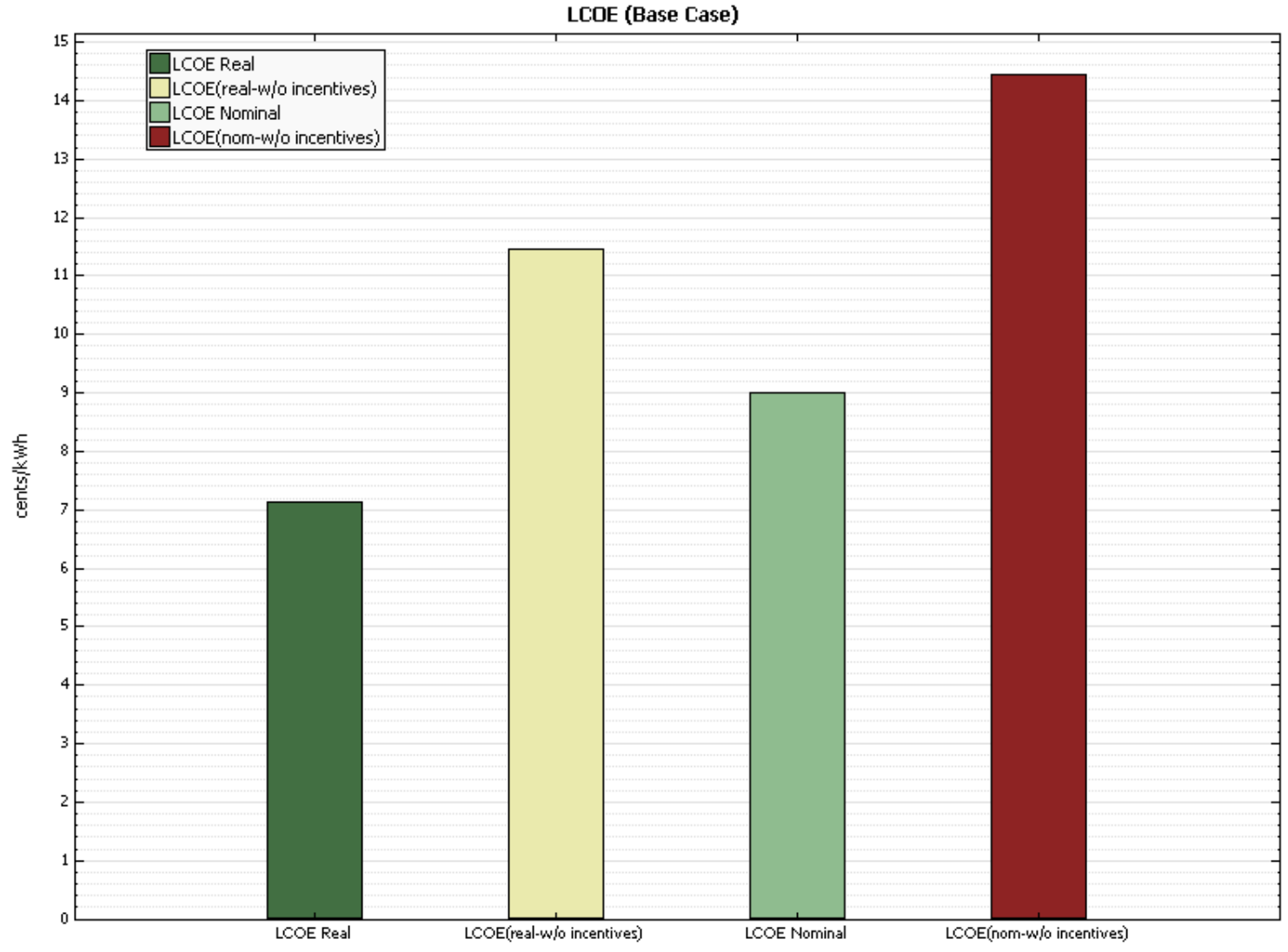

Figure B-1. LCOE for 5.5-MW roof system 


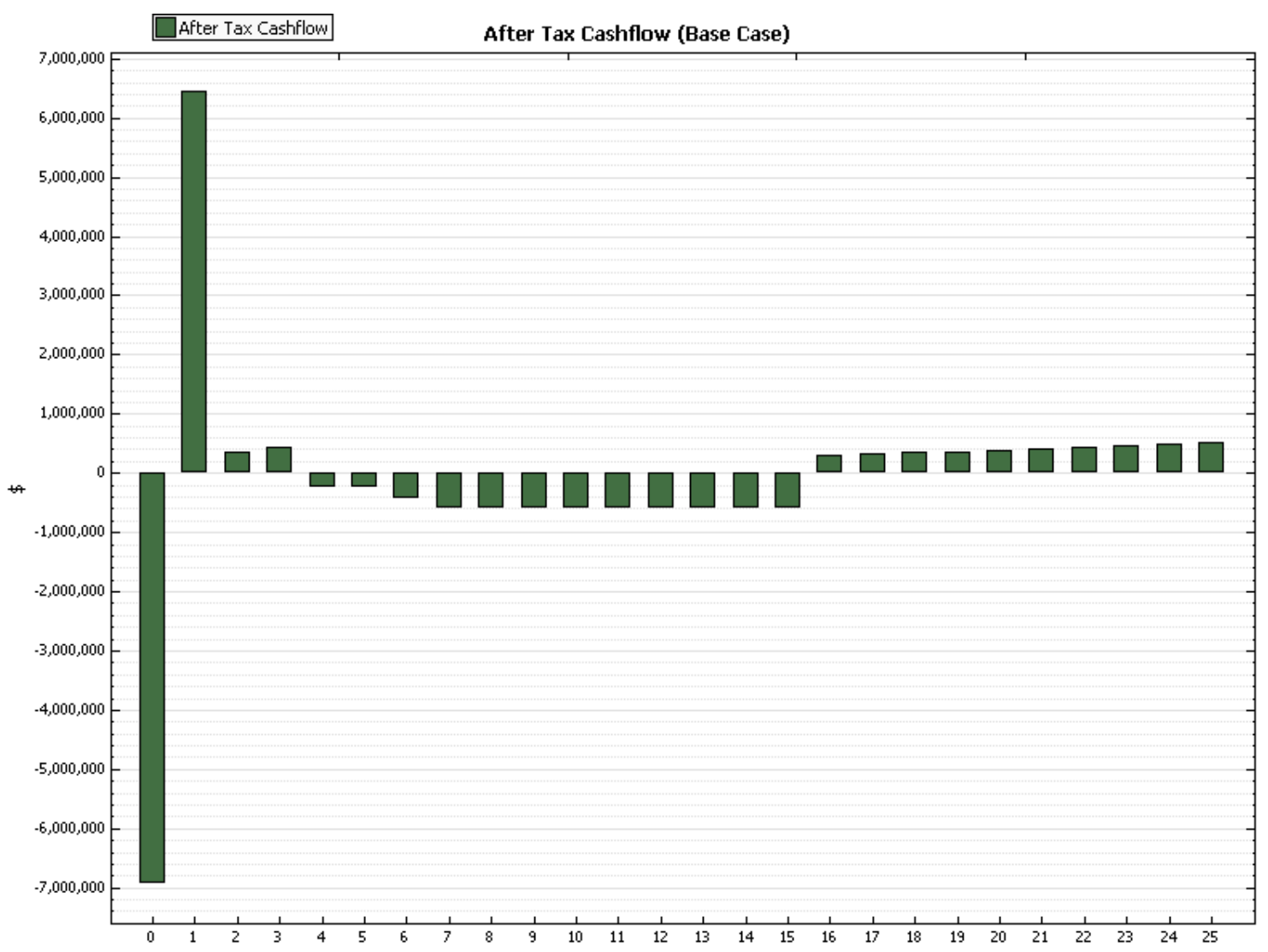

Figure B-2. After-tax cash flow for 5.5-MW roof system 


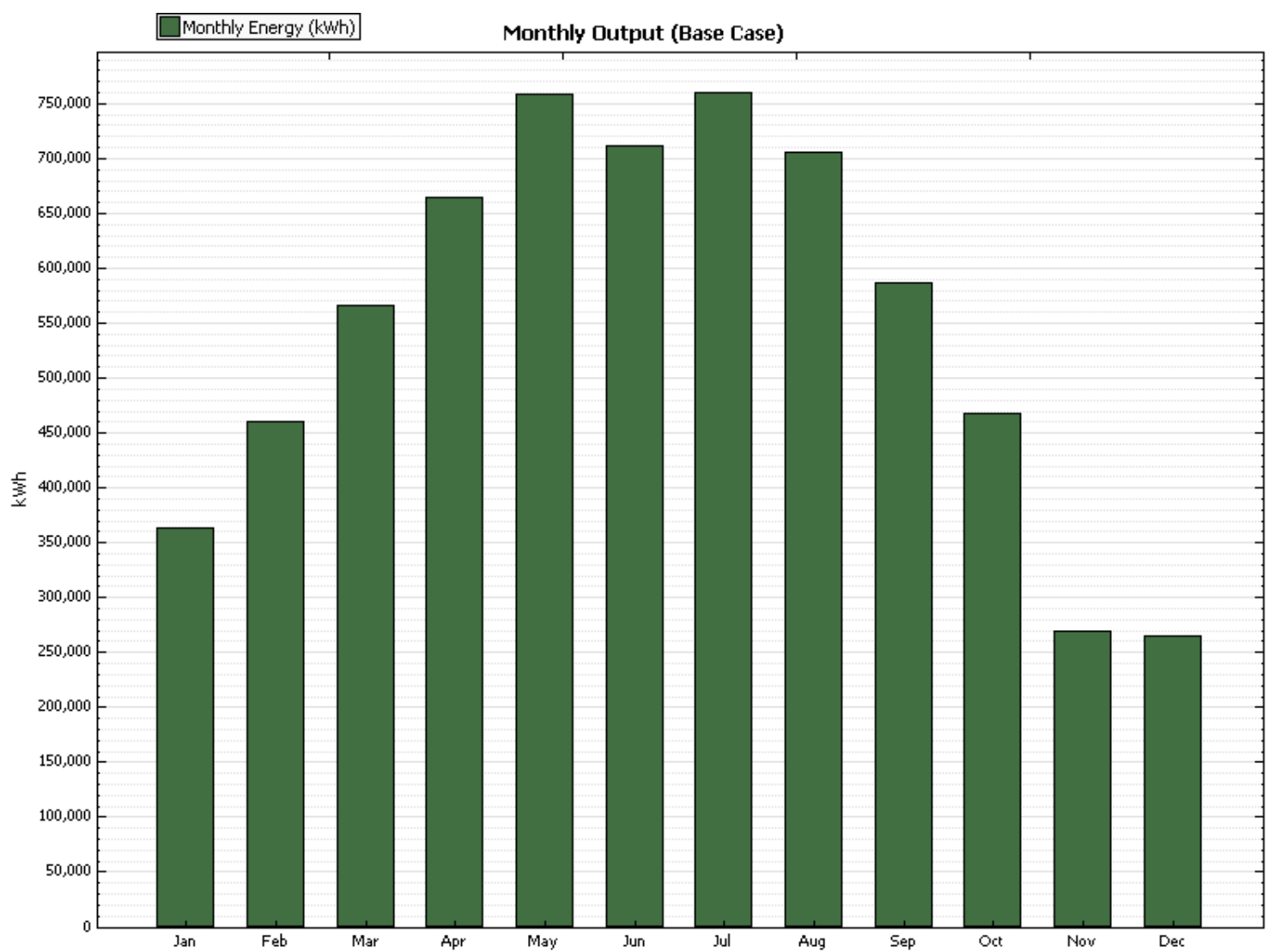

Figure B-3. Monthly energy output for 5.5-MW roof system 


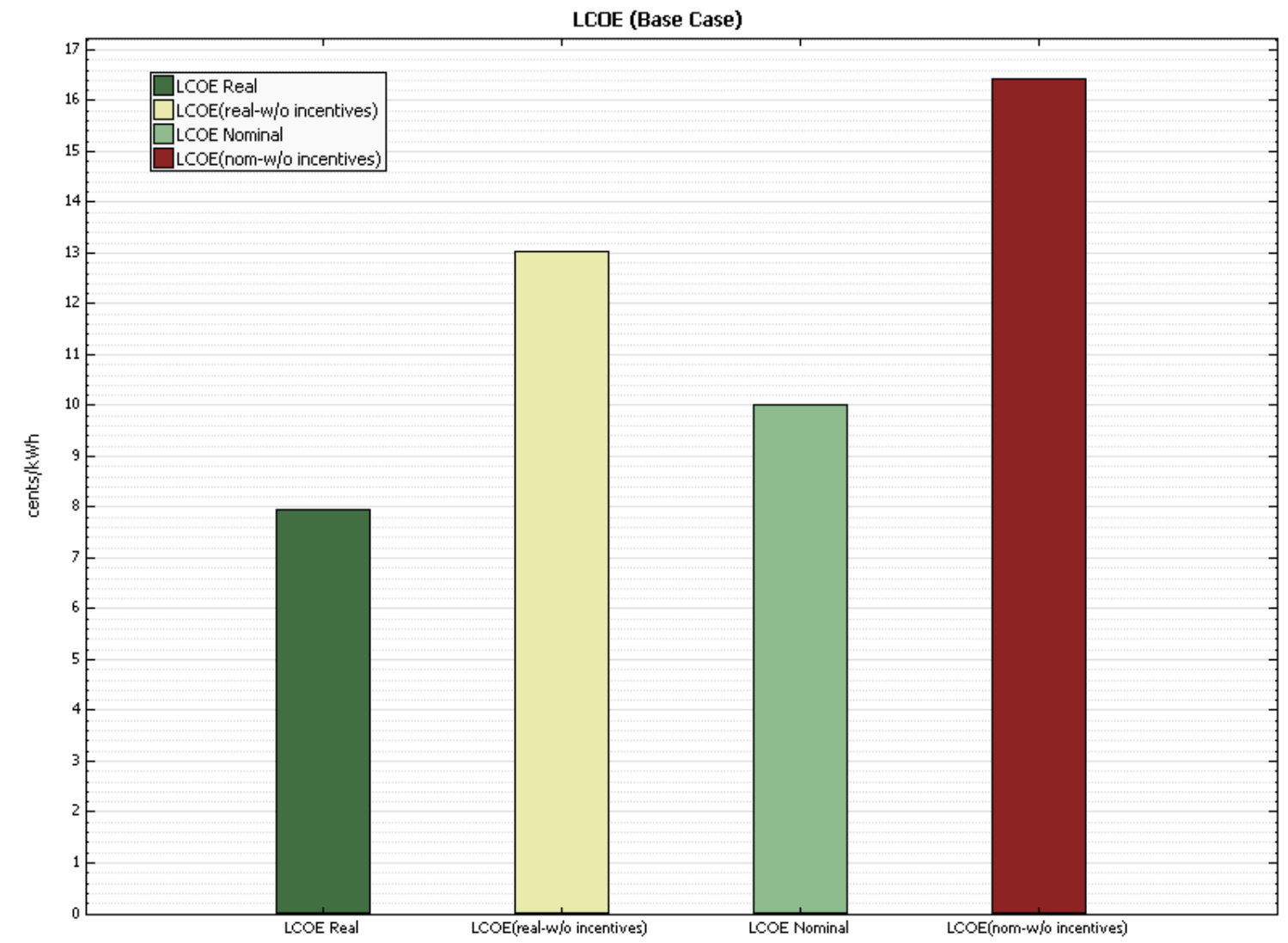

Figure B-4. LCE for 1.2-MW roof system 


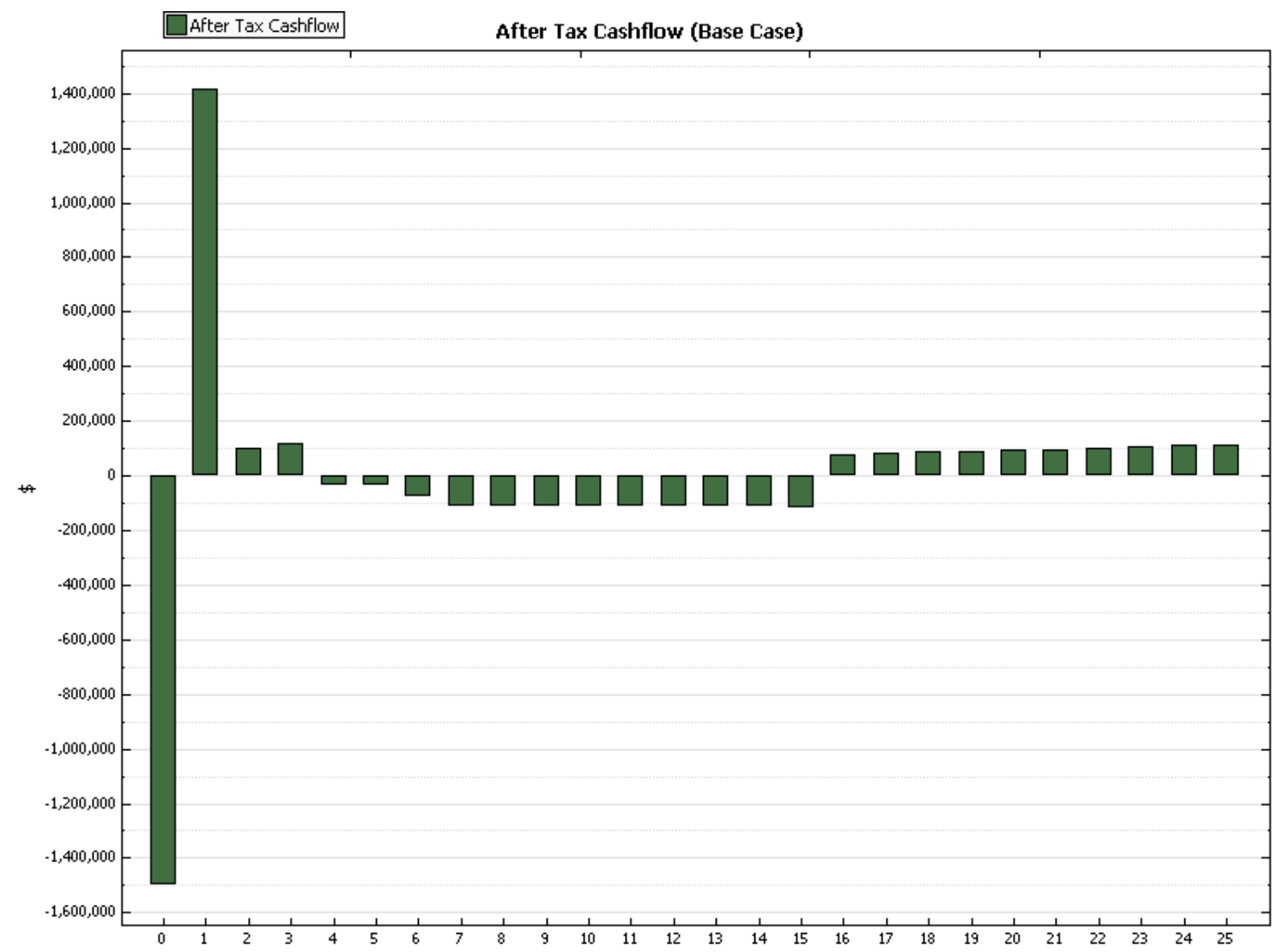

Figure B-5. After-tax cash flow for 1.2-MW roof system 


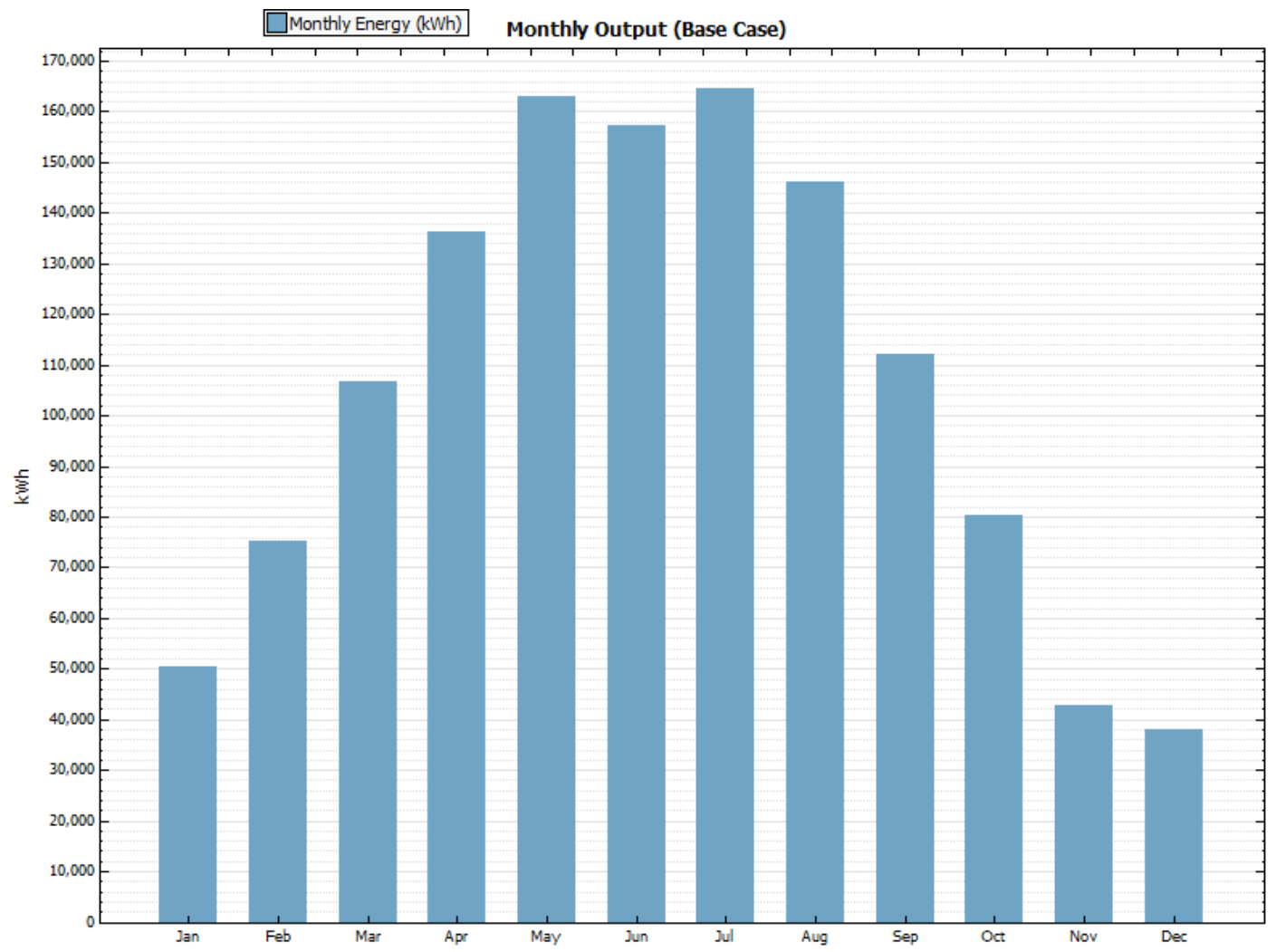

Figure B-6. Monthly energy output for 1.2-MW roof system 


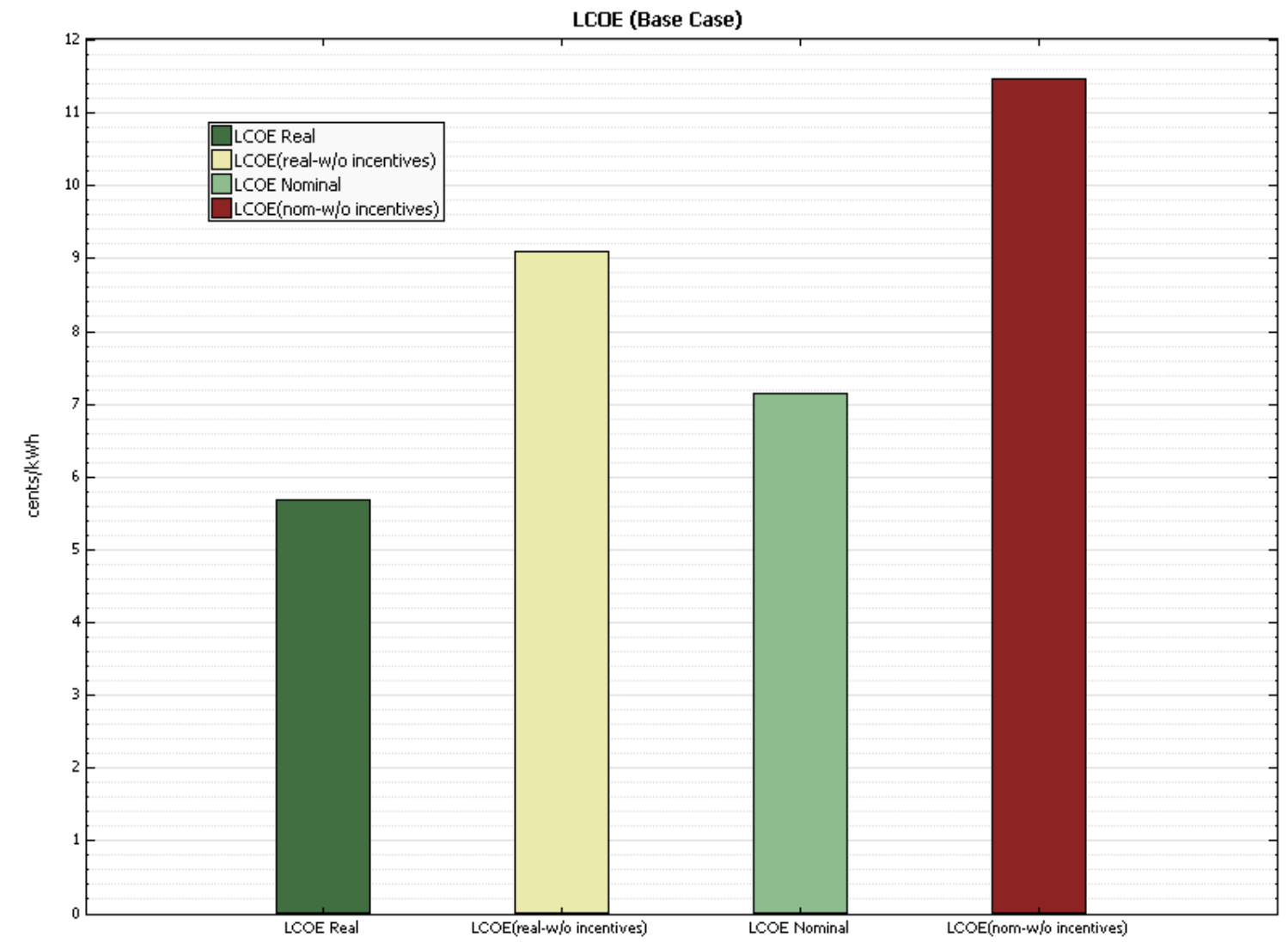

Figure B-7. LCOE for 2-MW net-metering roof system 


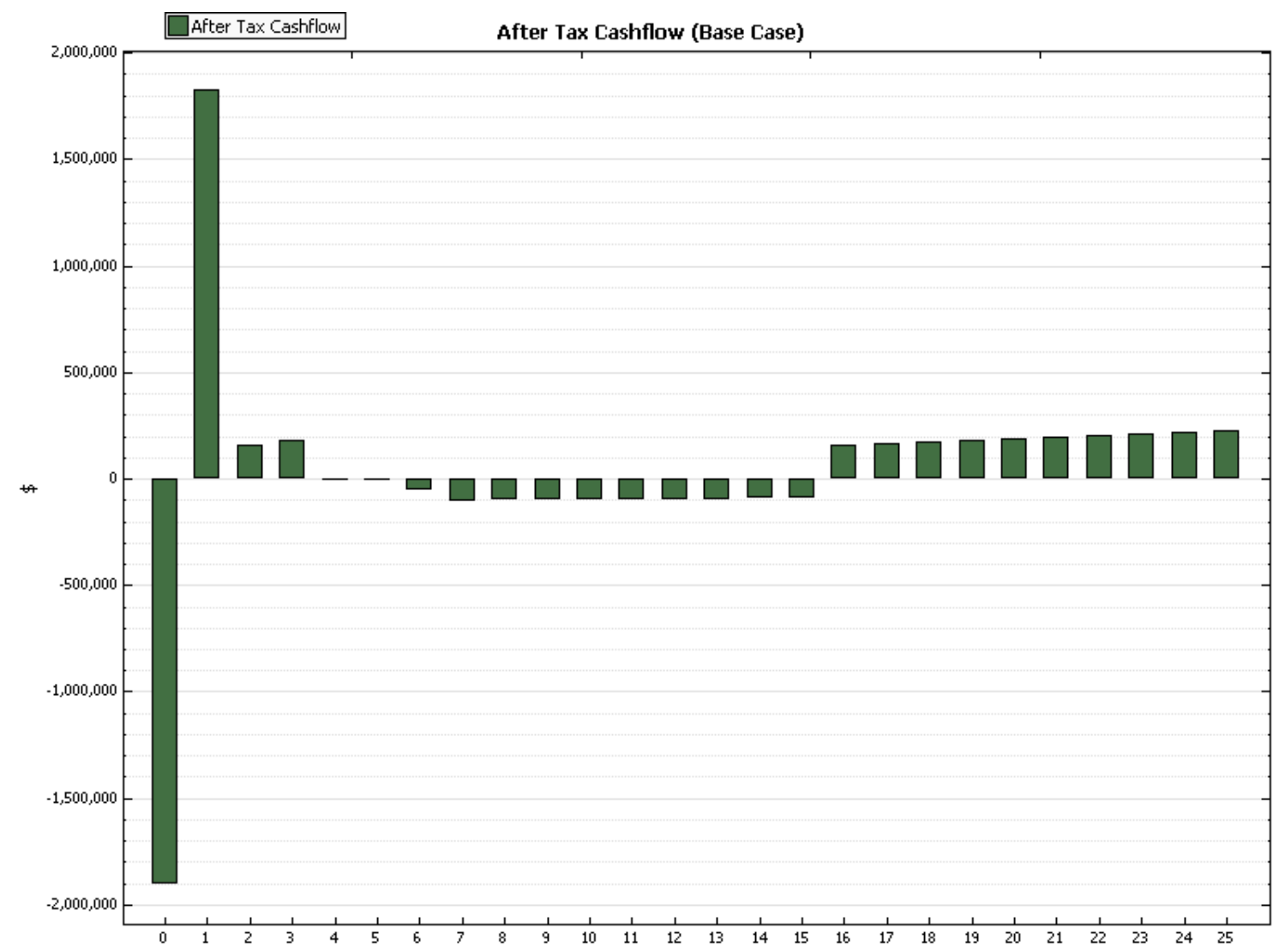

Figure B-8. After-tax cash flow for 2-MW roof system 


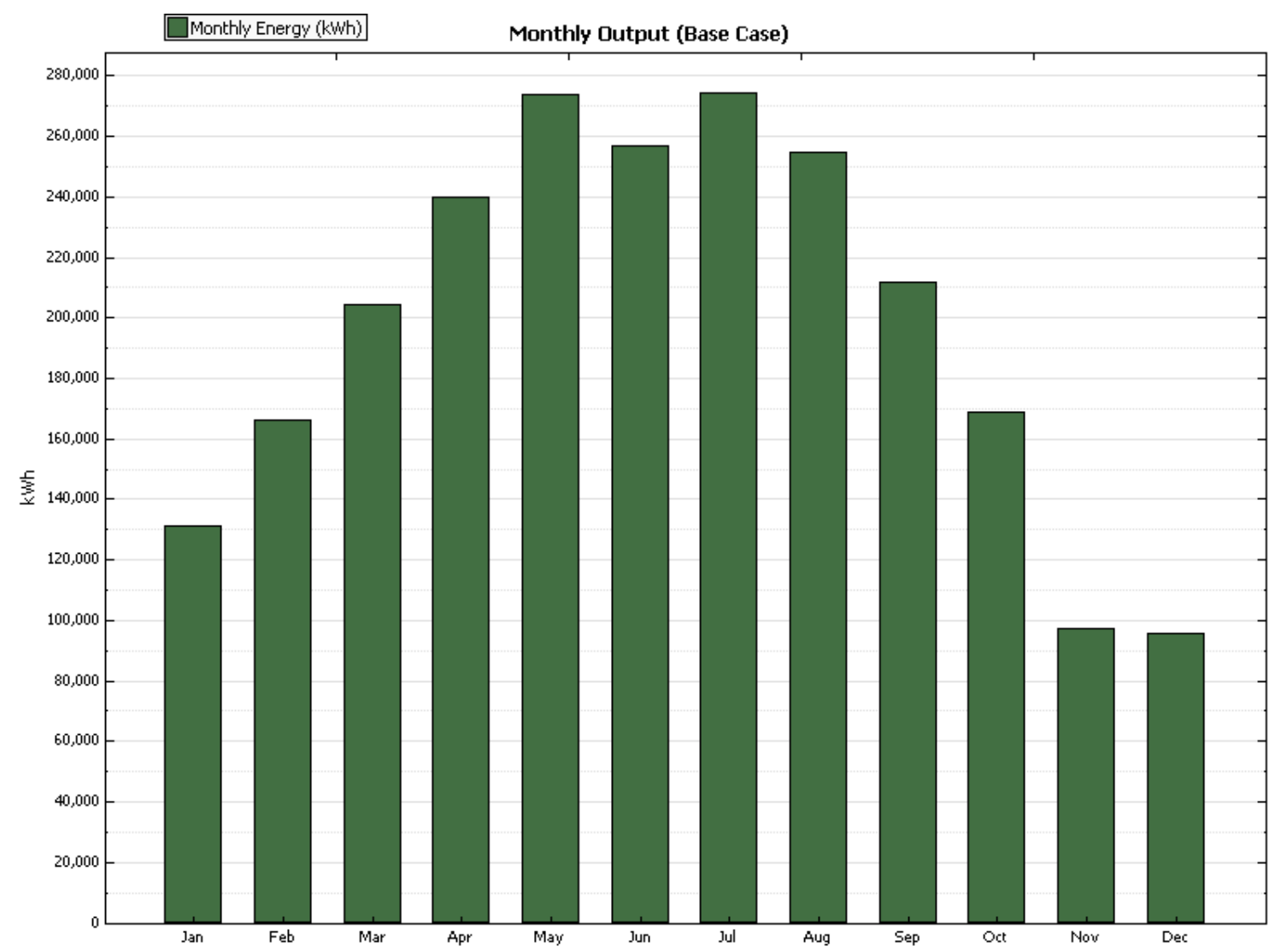

Figure B-9. Monthly energy output for 2-MW roof system 


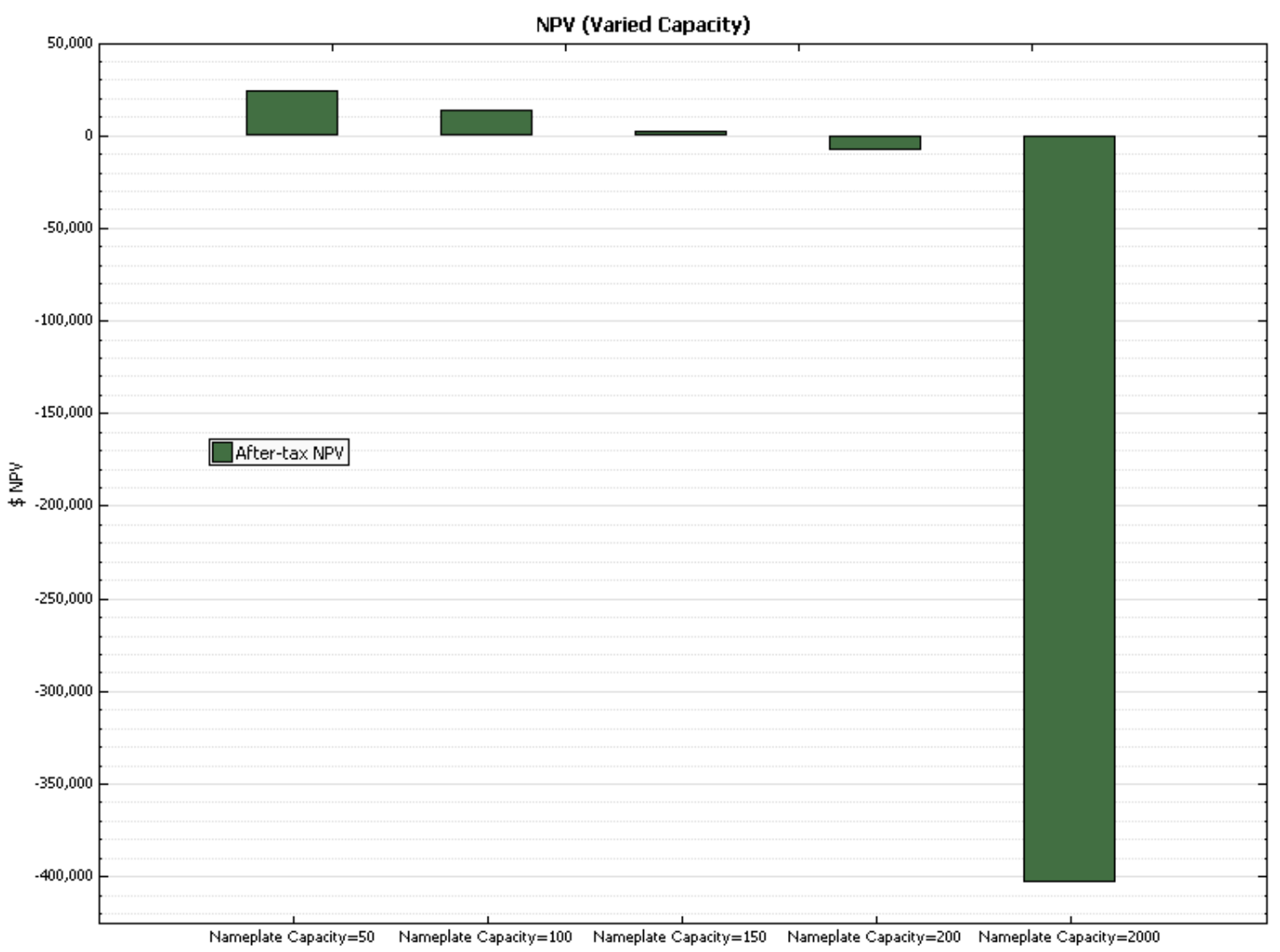

Figure B-10. Net-metering size determination for 2-MW roof system 


\section{Appendix C. Results of the Jobs and Economic Development Impact Model}

Appendix $\mathrm{C}$ shows the JEDI results from installing a 161-kW roof-mounted system. Other PV system sizes will be relative to this.

Table C-1. Photovoltaic Project Data Summary 161-kW Roof-Mounted System

\begin{tabular}{||l|l||}
\hline Project Location & New York \\
\hline Year of Construction or Installation & 2013 \\
\hline Average System Size - DC Nameplate Capacity (kW) & 161.0 \\
\hline Number of Systems Installed & 1 \\
\hline Project Size - DC Nameplate Capacity (kW) & 161.0 \\
\hline System Application & Utility \\
\hline Solar Cell/Module Material & Crystalline \\
\hline System Tracking & Fixed Mount \\
\hline Total System Base Cost (\$/kW DC) & $\$ 2,850$ \\
\hline $\begin{array}{l}\text { Annual Direct Operations and Maintenance Cost } \\
\text { (\$/kW) }\end{array}$ & $\$ 25.00$ \\
\hline Money Value - Current or Constant (Dollar Year) & 2012 \\
\hline Project Construction or Installation Cost & $\$ 458,859$ \\
\hline Local Spending & $\$ 217,143$ \\
\hline Total Annual Operational Expenses & $\$ 56,195$ \\
\hline Direct Operating and Maintenance Costs & $\$ 4,025$ \\
\hline Local Spending & $\$ 3,703$ \\
\hline Other Annual Costs & $\$ 52,170$ \\
\hline Local Spending & $\$ 64$ \\
\hline Debt Payments & $\$ 0$ \\
\hline Property Taxes & $\$ 0$ \\
\hline \hline
\end{tabular}


Table C-2. Local Economic Impacts-Summary Results

\begin{tabular}{|c|c|c|c|}
\hline During Construction and Installation Period & Jobs & $\begin{array}{c}\text { Earnings } \\
\$ 000(2012)\end{array}$ & $\begin{array}{c}\text { Output } \\
\$ 000(2012) \\
\end{array}$ \\
\hline \multicolumn{4}{|l|}{ Project Development and Onsite Labor Impacts } \\
\hline Construction and Installation Labor & 0.6 & $\$ 40.9$ & \\
\hline Construction and Installation Related Services & 0.6 & $\$ 34.0$ & \\
\hline Subtotal & 1.2 & $\$ 74.9$ & $\$ 124.8$ \\
\hline \multicolumn{4}{|l|}{ Module and Supply Chain Impacts } \\
\hline Manufacturing Impacts & 0.0 & $\$ 0.0$ & $\$ 0.0$ \\
\hline Trade (Wholesale and Retail) & 0.1 & $\$ 8.9$ & $\$ 25.5$ \\
\hline Finance, Insurance, and Real Estate & 0.0 & $\$ 0.0$ & $\$ 0.0$ \\
\hline Professional Services & 0.2 & $\$ 10.5$ & $\$ 31.7$ \\
\hline Other Services & 0.3 & $\$ 26.9$ & $\$ 87.9$ \\
\hline Other Sectors & 0.4 & $\$ 12.2$ & $\$ 24.3$ \\
\hline Subtotal & 1.0 & $\$ 58.4$ & $\$ 169.3$ \\
\hline Induced Impacts & 0.7 & $\$ 39.1$ & $\$ 124.6$ \\
\hline Total Impacts & 3.0 & $\$ 172.4$ & $\$ 418.7$ \\
\hline During Operating Years & $\begin{array}{c}\text { Annual } \\
\text { Jobs }\end{array}$ & $\begin{array}{c}\text { Annual } \\
\text { Earnings } \\
\$ 000(2012)\end{array}$ & $\begin{array}{c}\text { Annual } \\
\text { Output } \\
\$ 000(2012) \\
\end{array}$ \\
\hline \multicolumn{4}{|l|}{ Onsite Labor Impacts } \\
\hline PV Project Labor Only & 0.0 & $\$ 2.2$ & $\$ 2.2$ \\
\hline Local Revenue and Supply Chain Impacts & 0.0 & $\$ 0.8$ & $\$ 2.2$ \\
\hline Induced Impacts & 0.0 & $\$ 0.5$ & $\$ 1.5$ \\
\hline Total Impacts & 0.1 & $\$ 3.5$ & $\$ 6.0$ \\
\hline
\end{tabular}

Notes: Earnings and output values are thousands of dollars in year 2012 dollars. Construction and operating period jobs are full-time equivalent for one year (1 FTE $=2,080$ hours). Economic impacts "during operating years" represent impacts that occur from system/plant operations/expenditures. Totals might not add up due to independent rounding. 
Table C-3. Detailed PV Project Data Costs

\begin{tabular}{||l|l|l|l||}
\hline Installation Costs & \multicolumn{1}{|c|}{ Cost } & $\begin{array}{c}\text { Purchased } \\
\text { Locally (\%) }\end{array}$ & $\begin{array}{l}\text { Manufactured } \\
\text { Locally (Y or N) }\end{array}$ \\
\hline Materials and Equipment & & & \\
\hline Mounting (rails, clamps, fittings, etc.) & $\$ 16,381$ & $100 \%$ & $\mathrm{~N}$ \\
\hline Modules & $\$ 179,903$ & $100 \%$ & $\mathrm{~N}$ \\
\hline Electrical (wire, connectors, breakers, etc.) & $\$ 18,677$ & $100 \%$ & $\mathrm{~N}$ \\
\hline Inverter & $\$ 26,755$ & $100 \%$ & $\mathrm{~N}$ \\
\hline Subtotal & $\$ 241,716$ & & \\
\hline Labor & & & \\
\hline Installation & $\$ 40,929$ & $100 \%$ & \\
\hline Subtotal & $\$ 40,929$ & & \\
\hline Subtotal & $\$ 282,645$ & & \\
\hline Other Costs & & & \\
\hline Permitting & $\$ 1,891$ & $100 \%$ & \\
\hline Other Costs & $\$ 41,798$ & $100 \%$ & \\
\hline Business Overhead & $\$ 122,856$ & $100 \%$ & \\
\hline Subtotal & $\$ 166,545$ & & \\
\hline Subtotal & $\$ 449,190$ & & \\
\hline $\begin{array}{l}\text { Sales Tax (materials and equipment } \\
\text { purchases) }\end{array}$ & $\$ 9,669$ & $100 \%$ & \\
\hline Total & $\$ 458,859$ & & \\
\hline \hline
\end{tabular}


Table C-4. PV System Annual Operating and Maintenance Costs

\begin{tabular}{|c|c|c|c|}
\hline & Cost & Local Share & $\begin{array}{l}\text { Manufactured } \\
\text { Locally } \\
\text { (Y or N) }\end{array}$ \\
\hline \multicolumn{4}{|l|}{ Labor } \\
\hline Technicians & $\$ 2,415$ & $100 \%$ & \\
\hline Subtotal & $\$ 2,415$ & & \\
\hline \multicolumn{4}{|l|}{ Materials and Services } \\
\hline $\begin{array}{l}\text { Materials and } \\
\text { Equipment }\end{array}$ & $\$ 1,610$ & $100 \%$ & $\mathrm{~N}$ \\
\hline Services & $\$ 0$ & $100 \%$ & \\
\hline Subtotal & $\$ 181$ & & \\
\hline $\begin{array}{l}\text { Sales Tax (materials and } \\
\text { equipment purchases) }\end{array}$ & $\$ 9$ & $100 \%$ & \\
\hline $\begin{array}{l}\text { Average Annual Payment } \\
\text { (interest and principal) }\end{array}$ & $\$ 5,178$ & $0 \%$ & \\
\hline Property Taxes & $\$ 0$ & $100 \%$ & \\
\hline Total & $\$ 5,588$ & & \\
\hline \multicolumn{4}{|l|}{ Financial Parameters } \\
\hline \multicolumn{4}{|l|}{ Debt Financing } \\
\hline Percentage Financed & $80 \%$ & $0 \%$ & \\
\hline Years Financed (term) & 10 & & \\
\hline Interest Rate & $10 \%$ & & \\
\hline \multicolumn{4}{|l|}{ Tax Parameters } \\
\hline $\begin{array}{l}\text { Local Property Tax } \\
\text { (percent of taxable value) }\end{array}$ & $0 \%$ & & \\
\hline $\begin{array}{l}\text { Assessed Value (percent } \\
\text { of construction cost) }\end{array}$ & $0 \%$ & & \\
\hline $\begin{array}{l}\text { Taxable Value (percent of } \\
\text { assessed value) }\end{array}$ & $0 \%$ & & \\
\hline Taxable Value & $\$ 0$ & & \\
\hline $\begin{array}{l}\text { Property Tax Exemption } \\
\text { (percent of local taxes) }\end{array}$ & $100 \%$ & & \\
\hline Local Property Taxes & $\$ 0$ & $100 \%$ & \\
\hline Local Sales Tax Rate & $4.00 \%$ & $100 \%$ & \\
\hline $\begin{array}{c}\text { Sales Tax Exemption } \\
\text { (percent of local taxes) }\end{array}$ & $0 \%$ & & \\
\hline Payroll Parameters & Wage Per Hour & $\begin{array}{c}\text { Employer Payroll } \\
\text { Overhead }\end{array}$ & \\
\hline \multicolumn{4}{|l|}{$\begin{array}{l}\text { Construction and } \\
\text { Installation Labor }\end{array}$} \\
\hline $\begin{array}{c}\text { Construction } \\
\text { Workers/Installers }\end{array}$ & $\$ 21.39$ & $45.6 \%$ & \\
\hline \multicolumn{4}{|l|}{ O\&M Labor } \\
\hline Technicians & $\$ 21.39$ & $45.6 \%$ & \\
\hline
\end{tabular}

